\title{
Dissociations in the Effects of $\boldsymbol{\beta}_{2}$-Adrenergic Receptor Agonists on CAMP Formation and Superoxide Production in Human Neutrophils: Support for the Concept of Functional Selectivity
}

\author{
Irena Brunskole Hummel ${ }^{1,2}$, Michael T. Reinartz ${ }^{1}$, Solveig Kälble ${ }^{1}$, Heike Burhenne ${ }^{1}$, Frank Schwede ${ }^{3}$, \\ Armin Buschauer ${ }^{2}$, Roland Seifert ${ }^{1 *}$ \\ 1 Institute of Pharmacology, Medical School of Hannover, Hannover, Germany, 2 Department of Pharmaceutical and Medicinal Chemistry II, University of Regensburg,
} Regensburg, Germany, 3 Biolog Life Science Institute, Bremen, Germany

\begin{abstract}
In neutrophils, activation of the $\beta_{2}$-adrenergic receptor $\left(\beta_{2} A R\right)$, a $G_{s}$-coupled receptor, inhibits inflammatory responses, which could be therapeutically exploited. The aim of this study was to evaluate the effects of various $\beta_{2} A R$ ligands on adenosine- $3^{\prime}, 5^{\prime}$-cyclic monophosphate (cAMP) accumulation and N-formyl-L-methionyl-L-leucyl-L-phenylalanine (fMLP)induced superoxide anion $\left(\mathrm{O}_{2}{ }^{-}\right)$production in human neutrophils and to probe the concept of ligand-specific receptor conformations (also referred to as functional selectivity or biased signaling) in a native cell system. This is an important question because so far, evidence for functional selectivity has been predominantly obtained with recombinant systems, due to the inherent difficulties to genetically manipulate human native cells. CAMP concentration was determined by HPLC/ tandem mass spectrometry, and $\mathrm{O}_{2}^{--}$formation was assessed by superoxide dismutase-inhibitable reduction of ferricytochrome c. $\beta_{2} A R$ agonists were generally more potent in inhibiting $\mathrm{fMLP}$-induced $\mathrm{O}_{2}{ }^{--}$production than in stimulating CAMP accumulation. (-)-Ephedrine and dichloroisoproterenol were devoid of any agonistic activity in the cAMP assay, but partially inhibited fMLP-induced $\mathrm{O}_{2}{ }^{--}$production. Moreover, (-)-adrenaline was equi-efficacious in both assays whereas the efficacy of salbutamol was more than two-fold higher in the $\mathrm{O}_{2}^{\cdot-}$ assay. Functional selectivity was visualized by deviations of ligand potencies and efficacies from linear correlations for various parameters. We obtained no evidence for involvement of protein kinase $A$ in the inhibition of $\mathrm{AMLP}$-induced $\mathrm{O}_{2}{ }^{\cdot-}$ production after $\beta_{2} \mathrm{AR}$-stimulation although cAMPincreasing substances inhibited $\mathrm{O}_{2}{ }^{\cdot-}$ production. Taken together, our data corroborate the concept of ligand-specific receptor conformations with unique signaling capabilities in native human cells and suggest that the $\beta_{2} A R$ inhibits $\mathrm{O}_{2}{ }^{--}$ production in a CAMP-independent manner.
\end{abstract}

Citation: Brunskole Hummel I, Reinartz MT, Kälble S, Burhenne H, Schwede F, et al. (2013) Dissociations in the Effects of $\beta_{2}$-Adrenergic Receptor Agonists on CAMP Formation and Superoxide Production in Human Neutrophils: Support for the Concept of Functional Selectivity. PLoS ONE 8(5): e64556. doi:10.1371/ journal.pone.0064556

Editor: Chih-Hsin Tang, China Medical University, Taiwan

Received January 17, 2013; Accepted April 15, 2013; Published May 31, 2013

Copyright: (c) 2013 Brunskole Hummel et al. This is an open-access article distributed under the terms of the Creative Commons Attribution License, which permits unrestricted use, distribution, and reproduction in any medium, provided the original author and source are credited.

Funding: This work was supported by the Research Training Program GRK760 "Medicinal Chemistry: Molecular Recognition - Ligand-Receptor Interactions" of the German Research Foundation (Deutsche Forschungsgemeinschaft, DFG). The funders had no role in study design, data collection and analysis, decision to publish, or preparation of the manuscript.

Competing Interests: Roland Seifert serves as an Academic Editor for PLOS ONE. This does not alter the authors' adherence to all the PLOS ONE policies on sharing data and materials.

* E-mail: seifert.roland@mh-hannover.de

\section{Introduction}

Human neutrophils are crucial for the defense of the host organism against infectious agents such as bacteria, fungi, protozoa, viruses and tumor cells. After phagocytosis of invading agents neutrophils are able to destruct them, the respiratory burst NADPH oxidase being a major player [1]. This enzyme catalyzes the univalent reduction of molecular oxygen $\left(\mathrm{O}_{2}\right)$ to the superoxide anion $\left(\mathrm{O}_{2}{ }^{--}\right)$with NADPH as electron donor [2-5]. Activation of neutrophils is triggered by bacterial formyl peptides [6]. Upon binding of N-formyl-L-methionyl-L-leucyl-L-phenylalanine (fMLP) to the formyl peptide receptor, which is $\mathrm{G}_{\mathrm{i}}$-coupled [7-8], $\mathrm{O}_{2}{ }^{--}$production in neutrophils increases [1]. fMLPstimulated $\mathrm{O}_{2}{ }^{--}$production in neutrophils is counteracted by compounds that increase the intracellular adenosine- $3^{\prime}, 5^{\prime}$-cyclic monophosphate (cAMP) concentration [2]. These compounds include prostaglandins, the inhibitor of phosphodiesterases, 3isobutyl-1-methylxanthine (IBMX), membrane-permeable analogs of cAMP as well as agonists of the $\beta_{2}$-adrenergic receptor $\left(\beta_{2} \mathrm{AR}\right)$ [9-14]. Furthermore, fMLP-stimulated $\mathrm{O}_{2}{ }^{-}$formation is enhanced by the incubation of neutrophils with $\mathcal{N}-(2-\{[(E)-3-(4-$ bromophenyl)prop-2-enyl] amino ethyl)isoquinoline-5-sulfonamide (H-89), an inhibitor of cAMP-dependent protein kinase (PKA) [11]. Canonically, the $\beta_{2} \mathrm{AR}$ couples to $\mathrm{G}_{\mathrm{s}}$ proteins in order to activate adenylyl cyclases (AC) resulting in increased intracellular cAMP concentration [2]. Nevertheless, the $\beta_{2} \mathrm{AR}$ can also couple to $G_{i}$ proteins, $G_{q}$ proteins and $\beta$-arrestin, triggering responses distinct from those activated through $\mathrm{G}_{\mathrm{s}}$ proteins [1519]. 
Table 1. Comparison of potencies and efficacies of standard $\beta_{2} A R$ agonists, determined in three different test systems.

\begin{tabular}{|c|c|c|c|c|c|c|}
\hline \multirow[t]{2}{*}{ Cpd. } & \multicolumn{2}{|c|}{$\begin{array}{l}\mathrm{O}_{2}{ }^{\cdot-} \text { assay }\left(\beta_{2} A R \text { on neutrophil }\right. \\
\text { granulocytes) }\end{array}$} & \multicolumn{2}{|c|}{$\begin{array}{l}\text { CAMP assay ( } \beta_{2} A R \text { on neutrophil } \\
\text { granulocytes) }\end{array}$} & \multicolumn{2}{|c|}{$\begin{array}{l}\text { GTPase assay (recombinant protein } \\
\left.h \beta_{2} A R-G_{\text {sas }}\right)\end{array}$} \\
\hline & $\begin{array}{l}\text { PIC } \\
\left(I C_{50} \pm \text { in } \mu M . \text { E.M. }\right.\end{array}$ & $E_{\max } \pm$ S.E.M. & $\begin{array}{l}\text { pEC }_{50} \pm \text { S.E.M. } \\
\left(E C_{50} \text { in } \mu M\right)\end{array}$ & $E_{\max } \pm$ S.E.M. & $\begin{array}{l}\text { pEC } \\
\text { (E0 } \pm \text { S.E.M. } \\
\left(E C_{50} \text { in } \mu M\right)\end{array}$ & $E_{\max } \pm$ S.E.M. \\
\hline ISO & $8.02 \pm 0.07(0.0096)$ & 1.00 & $7.42 \pm 0.10(0.038)$ & 1.00 & $7.50^{\mathbf{b}}(0.032)$ & $1.00^{\mathrm{b}, \mathrm{c}}$ \\
\hline ADR & $7.82 \pm 0.09(0.015)$ & $1.01 \pm 0.05$ & $6.81 \pm 0.09(0.16)$ & $1.06 \pm 0.04$ & $7.37^{c}(0.043)$ & $1.00^{c}$ \\
\hline SAL & $7.16 \pm 0.12(0.069)$ & $0.77 \pm 0.04$ & $6.74 \pm 0.15(0.18)$ & $0.35 \pm 0.03$ & $6.70^{\mathbf{b}}(0.20)$ & $0.74^{\mathbf{b}}$ \\
\hline DOB & n.d. & $0.15 \pm 0.03^{a}$ & $4.86 \pm 0.36(13.8)$ & $0.21 \pm 0.05$ & $6.70^{\mathbf{b}}(0.20)$ & $0.45^{\mathbf{b}}$ \\
\hline EPH & $5.95 \pm 0.23(1.12)$ & $0.34 \pm 0.04$ & $<4(<100)$ & $0.01 \pm 0.01$ & $4.69^{\mathbf{b}}(20.5)$ & $0.31^{\mathbf{b}}$ \\
\hline DCI & $4.40 \pm 0.26(39.8)$ & $0.32 \pm 0.06$ & $<4(<100)$ & $0.00 \pm 0.01$ & $7.09^{\mathbf{b}}(0.082)$ & $0.17^{\mathbf{b}}$ \\
\hline
\end{tabular}

On human neutrophil granulocytes, the $\mathrm{O}_{2}{ }^{--}$assay $\left(1 \times 10^{5}\right.$ cells per well) and the cAMP assay $\left(5 \times 10^{5}\right.$ cells per cup) were performed as described under Materials and Methods. Data were analyzed by non-linear regression and were best fitted to sigmoidal concentration/response curves. Data shown are the means of four to nine independent experiments performed in triplicate. The efficacy $\left(E_{\max }\right)$ of ISO in each assay was set to 1.00 and the efficacies of other ligands were referred to this value. n.d. not determined. As DOB at concentrations higher than $500 \mathrm{nM}$ caused reduction of ferricytochrome c per se, the reliable determination of plC $C_{50}$ value was not possible. ${ }^{a}$ Efficacy at concentration of $500 \mathrm{nM}$ was taken as $E_{\max }{ }^{\text {b }}$ The data were taken from [45]. The reported non-logarithmic $\mathrm{EC}_{50}$ values were converted into logarithmic $\mathrm{pEC} 50$ values. ${ }^{\mathrm{C}}$ The data were taken from [43]. The non-logarithmic $\mathrm{EC}_{50}$ values shown in $\mu \mathrm{M}$ in parentheses were converted into logarithmic $\mathrm{pEC} \mathrm{C}_{50}$ value. The literature data on GTPase assay are lacking S.E.M., because the original data are represented in non-logarithmic manner and/or S.D. or $95 \%$ confidence interval is indicated instead of S.E.M. Therefore, calculation of S.E.M. from available data was impossible.

doi:10.1371/journal.pone.0064556.t001

Classic models of G-protein-coupled receptor (GPCR) activation postulate the existence of a single active $\left(\mathrm{R}^{*}\right)$ and an inactive (R) state [20-22]. In the active $\mathrm{R}^{*}$ state, the receptor is assumed to activate its cognate $\mathrm{G}$ protein and regulate down-stream effectors. However, over the past 15-20 years, compelling evidence from various groups has accumulated that the $R / R^{*}$ dichotomy is too simplicistic. These studies comprise biochemical, pharmacological and biophysical approaches [19-39]. Accordingly, it is now generally assumed that any given ligand stabilizes a ligand-specific receptor conformation with unique signaling capabilities, resulting in ligand-specific activation of G-proteins and/or $\beta$-arrestin $[27,28]$. Stabilization of ligand-specific receptor conformations with unique signaling capabilities is also referred to as functional selectivity or biased signaling [20-22,29-33]. To this end, most of the evidence for ligand-specific receptor conformations has been obtained in studies with recombinant systems [34-36] or purified receptor proteins [31,37-39], but studies on the relevance of ligand-specific receptor conformations in native human cells are still largely missing. Reasons for this lack of knowledge are inherent difficulties to manipulate human cells genetically. In addition, after isolation, human blood cells such as neutrophils survive only for limited period of time [40]. However, since the concept of functional selectivity implies that certain ligands can be clinically more efficacious in a given setting while displaying less unwanted effects, it is of paramount importance to probe functional selectivity in native cells.

Recently, we have reported on the functional selectivity of another $\mathrm{G}_{\mathrm{s}}$-coupled receptor, the histamine $\mathrm{H}_{2}$ receptor, in two native cell systems, human eosinophils and neutrophils [40]. The pharmacological profiles of $\mathrm{H}_{2} \mathrm{R}$ agonists as well as $\mathrm{H}_{2} \mathrm{R}$ antagonists do not match by comparing their effects on eosinophils and neutrophils as well as by comparing these parameters with data obtained in a recombinant test system. Moreover, even in the same cell type, differences were observed when ligands were characterized determining two different parameters. Each ligand triggers unique effects depending on the test system and parameters measured which is of importance for further drug development.

The aim of the present study was the characterization of the $\beta_{2} \mathrm{AR}$ on human neutrophils with a series of structurally diverse $\beta_{2} \mathrm{AR}$ ligands and thereby, to probe the concept of ligand-specific receptor conformations on one of the most important and bestcharacterized GPCRs in a physiologically relevant native human cell system. Two distinct parameters were chosen for the characterization of the $\beta_{2} \mathrm{AR}$ on neutrophils. The first parameter was measurement of the cAMP content in neutrophils. The second parameter was monitoring of the $\beta_{2} \mathrm{AR}$-mediated effects on fMLPstimulated $\mathrm{O}_{2}{ }^{--}$production. We also examined the effects of various pharmacological tools including protein kinase inhibitors, AC inhibitors and activators and various cAMP analogues on fMLP-induced $\mathrm{O}_{2}{ }^{--}$production in order to obtain further insights into the mechanisms underlying inhibition of NADPH oxidase.

\section{Materials and Methods}

\section{Materials}

$\left(S^{*}, S^{*}\right)$-3-(Isopropylamino)-1-(7-methyl-2,3-dihydro-1 $H$-inden-

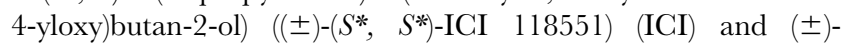
bisoprolol (BIS) were obtained from Tocris Bioscience (Avonmouth, Bristol, UK). (-)-Isoproterenol (ISO), (-)-adrenaline

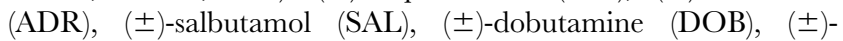
metoprolol (MET), ( \pm )-alprenolol (ALP), ( \pm )-atenolol (ATE) and forskolin (FSK) were from Sigma-Aldrich (St. Louis, MO, USA). (-)-Ephedrine (EPH) was from Mallinckrodt (St. Louis, MO, USA) and (士)-dichlorisoproterenol (DCI) from Aldrich (Milwaukee, WI, USA). Chemical structures of ligands are depicted in Fig. S1. Stock solutions of ISO, ADR, SAL, DOB, $\mathrm{EPH}$ and DCI (10 mM each) were prepared in $1 \mathrm{mM} \mathrm{HCl}$ and stock solutions of ICI, MET, ALP, BIS and ATE in Millipore water. Dilution series of all ligands were prepared in Millipore water. Dulbecco's PBS (DPBS, $10 \mathrm{x}$ ) without $\mathrm{Ca}^{2+}$ and $\mathrm{Mg}^{2+}$ ( $\mathrm{pH}$ 6.5-7.0) was purchased from PAN Biotech (Aidenbach, Germany) and Biocoll separating solution from Biochrom (Berlin, Germany). Trypan blue solution, ferricytochrome c, cytochalasin B, fMLP and IBMX were from Sigma-Aldrich. Solvents for extraction and HPLC analysis were purchased as follows: HPLC-gradient grade water and methanol from J. T. Baker (Deventer, The Netherlands), ammonium acetate from Sigma-Aldrich and acetic acid from Riedel-de Haen (HannoverSeelze, Germany). Tenofovir was obtained from the National 

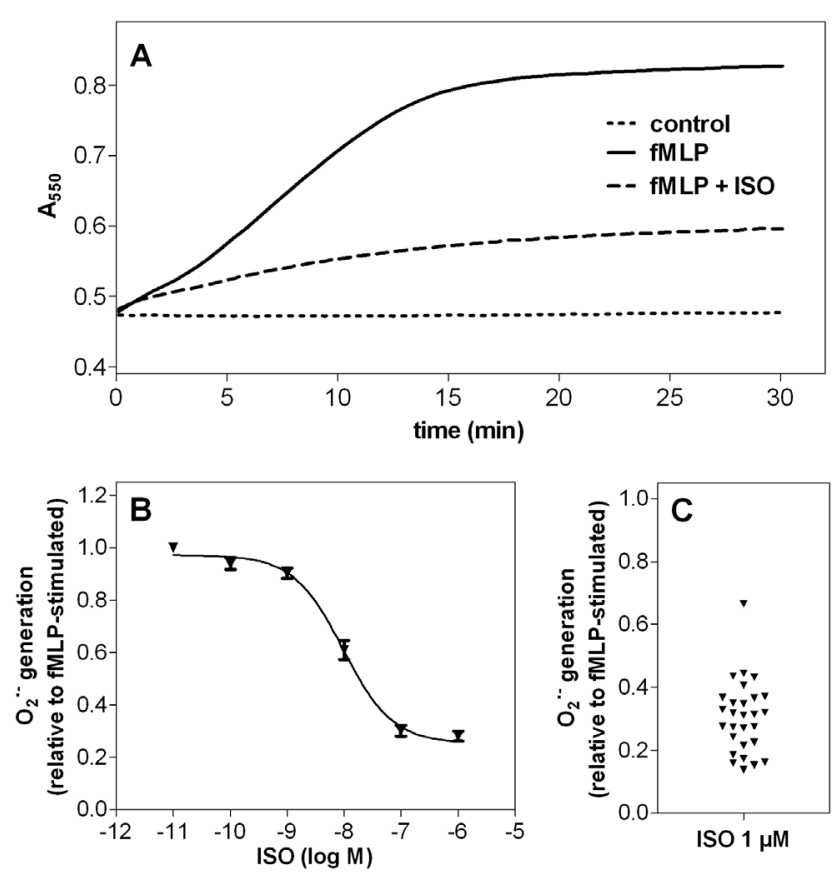

Figure 1. Superoxide anion generation assay $\left(\mathrm{O}_{2}{ }^{--}\right.$assay). The $\mathrm{O}_{2}^{--}$production in human neutrophil granulocytes $\left(1 \times 10^{5}\right.$ cells per well) was monitored by measuring the superoxide dismutase-inhibitable reduction of ferricytochrome $c$ at $550 \mathrm{~nm}$ as described under Materials and Methods. (A) Continuous measurement of $\mathrm{O}_{2}{ }^{--}$production for 30 min under control conditions (control), after stimulation with $1 \mu \mathrm{M}$ fMLP (fMLP) and in the presence of $1 \mu \mathrm{M} \mathrm{fMLP}$ in combination with $1 \mu \mathrm{M}$ ISO (fMLP+ISO). Data shown are from one representative experiment performed in triplicate. (B) Concentration-response curve for ISO in the $\mathrm{O}_{2}{ }^{--}$assay. Data shown are from nine independent experiments, performed in triplicate (data points are means \pm S.E.M.). Data were analyzed by non-linear regression and were best fitted to sigmoidal concentration/response curve. (C) Inter-experimental variability of inhibitory effect of $1 \mu \mathrm{M}$ ISO on fMLP-stimulated $\mathrm{O}_{2}{ }^{\cdot-}$ production. Each data point represents one independent experiment. Increase in absorbance at $550 \mathrm{~nm}$ during $30 \mathrm{~min}$ after addition of $\mathrm{fMLP}$ was set to 1.00 and increase in absorbance in the presence of $1 \mu \mathrm{M}$ ISO ( + fMLP) in each assay was compared to this value.

doi:10.1371/journal.pone.0064556.g001

Institutes of Health (Bethesda, MD, USA). $\mathrm{N}^{6}, 2^{\prime}$-O-dibutyryladenosine-3', $5^{\prime}$-cyclic monophosphate (DB-cAMP) (>96\%; <3\% monobutyryl derivatives; $<0.5 \%$ cAMP) was purchased from Sigma-Aldrich. cAMP $(>99.9 \%)$, adenosine- $3^{\prime}, 5^{\prime}$-cyclic monophosphorothioate, Rp-isomer (Rp-cAMPS) (>99.94\%), $\mathrm{N}^{6}$ monobutyryladenosine- $3^{\prime}, 5^{\prime}$-cyclic monophosphate (6-MBcAMP $\quad(>99.56 \%), \quad 2^{\prime}$-O-monobutyryladenosine- $3^{\prime}, 5^{\prime}$-cyclic monophosphate (2'-O-MB-cAMP) (>99.69\%), adenosine-3', $5^{\prime}$ cyclic monophosphorothioate, Sp-isomer (Sp-cAMPS) $(>99.96 \%)$, and 8-(4-chlorophenylthio)-2'-O-methyladenosine3', $5^{\prime}$-cyclic monophosphate (8-pCPT-2'-O-Me-cAMP) $(>99.97 \%)$ were obtained from BIOLOG Life Science Institute (Bremen, Germany). Structures of cAMP analogs are shown in Fig. S2. Purities of cyclic nucleotides were determined by HPLC. Stock solutions of nucleotides (100 mM each) were prepared with Millipore water. H89 was obtained from Merck (Darmstadt, Germany) as a $10 \mathrm{mM}$ solution in DMSO. KT5720 was from Enzo Life Sciences (Farmingdale, NY, USA) and a $10 \mathrm{mM}$ stock solution was prepared in DMSO. SQ 22536 (Merck, Darmstadt, Germany) was prepared as a $10 \mathrm{mM}$ solution in DMSO. FSK $(10 \mathrm{mM})$ was dissolved in DMSO as well. Phorbol-12-myristate-13-acetate was prepared as a $10 \mathrm{mM}$ solution in DMSO and was purchased from Sigma. Working solutions of all named substances were prepared by diluting stock solution with Millipore water.

\section{Isolation of Human Neutrophils}

This study and the consent procedure were approved by the Ethics Committee of the Medical School of Hannover. Written consent was obtained by all volunteers. The completed and signed consent forms are kept on file in the secretary of the Institute of Pharmacology of the Medical School of Hannover. Human neutrophils were isolated from venous blood of healthy volunteers of either sex $(1.6 \mathrm{mg} \mathrm{EDTA} / \mathrm{ml}$ blood as anticoagulant) or from buffy coat obtained from the Institute for Transfusion Medicine (Medical School of Hannover, Germany). Buffy coat preparations were also obtained from individual donors. All isolation steps were carried out at room temperature. Firstly, $7 \mathrm{ml}$ of venous blood or $5 \mathrm{ml}$ of buffy coat were diluted to $35 \mathrm{ml}$ with $1 \times$ DPBS and carefully layered onto $15 \mathrm{ml}$ of Biocoll separating solution (density $1.077 \mathrm{~g} / \mathrm{ml}$ ) in a $50 \mathrm{ml}$ Falcon tube. Following centrifugation (30 min, $400 \times \mathrm{g}$ ), the upper three layers were removed. The residual pellet $(\sim 2 \mathrm{ml})$, which contained erythrocytes and granulocytes, was resuspended in $18 \mathrm{ml}$ of Millipore water and incubated for $1 \mathrm{~min}$ under gentle agitation in order to achieve selective lysis of erythrocytes. Afterwards, isotonicity was restored by adding $2.2 \mathrm{ml}$ of $10 \times \mathrm{DPBS}$, and centrifugation at $300 \times \mathrm{g}$ for $5 \mathrm{~min}$ followed. The lysis step was repeated once to remove residual erythrocytes. The cell pellet was re-suspended in $5 \mathrm{ml}$ of $1 \times$ DPBS and sedimented by centrifugation at $300 \times \mathrm{g}$ for $5 \mathrm{~min}$. The resulting cell preparation consisted of viable neutrophils $(>98 \%)$, as assessed by the trypan blue exclusion test. Finally, neutrophils were suspended in $1 \times \mathrm{PBS}\left(1 \times 10^{6}\right.$ cells $/ \mathrm{ml}$ for the $\mathrm{O}_{2}{ }^{--}$assay or $1 \times 10^{7}$ cells $/ \mathrm{ml}$ for the determination of cAMP) and stored on ice until use. Experiments were performed within $4 \mathrm{~h}$ after completion of isolation because at later time points, viability of cells declined substantially as assessed by trypan blue dye uptake and declined responsiveness to receptor ligands (data not shown).

\section{Superoxide Anion Generation $\left(\mathrm{O}_{2}{ }^{--}\right.$Assay $)$}

Reactions were carried out in 96-well plates in triplicate. Standard reaction mixtures (total volume $200 \mu \mathrm{l}$ ) contained $1 \mathrm{mM}$ $\mathrm{CaCl}_{2}, 100 \mu \mathrm{M}$ ferricytochrome c, $0.3 \mu \mathrm{g} / \mathrm{ml}$ cytochalasin B (priming role by enhancing $\mathrm{O}_{2}{ }^{--}$formation upon exposure to fMLP) [2], ligands at different concentrations (where indicated, additionally PKA inhibitors, AC inhibitors or cAMP analogs) and $1 \times 10^{5}$ neutrophils in $1 \times$ DPBS. After pre-incubation of the reaction mixtures for $3 \mathrm{~min}$ at $37^{\circ} \mathrm{C}$, reactions were initiated by addition of fMLP $(1 \mu \mathrm{M})$. Reference samples contained all components listed above except for fMLP. $\mathrm{O}_{2}{ }^{--}$formation was continuously measured by monitoring the reduction of ferricytochrome c at $550 \mathrm{~nm}$ for $30 \mathrm{~min}$ at $37^{\circ} \mathrm{C}$, using a Synergy 4 microplate reader (BioTek Instruments, Winooski, VT, USA). The difference in absorbance at $550 \mathrm{~nm}$ between 0 min (addition of fMLP) and 30 min was used for subsequent data analysis, in order to assess agonistic activity of examined ligands. With the exception of DOB, all examined test compounds did neither reduce ferricytochrome $\mathrm{c}$ nor stimulate $\mathrm{O}_{2}{ }^{--}$production per se nor acted as radical scavenger as assessed by the lack of effect on phorbol ester-stimulated $\mathrm{O}_{2}{ }^{--}$production (data not shown). As at DOB concentrations higher than $500 \mathrm{nM}$, ferricytochrome c reduction took place, the maximum concentration of DOB used in the $\mathrm{O}_{2}{ }^{-}$ assays was $500 \mathrm{nM}$. 

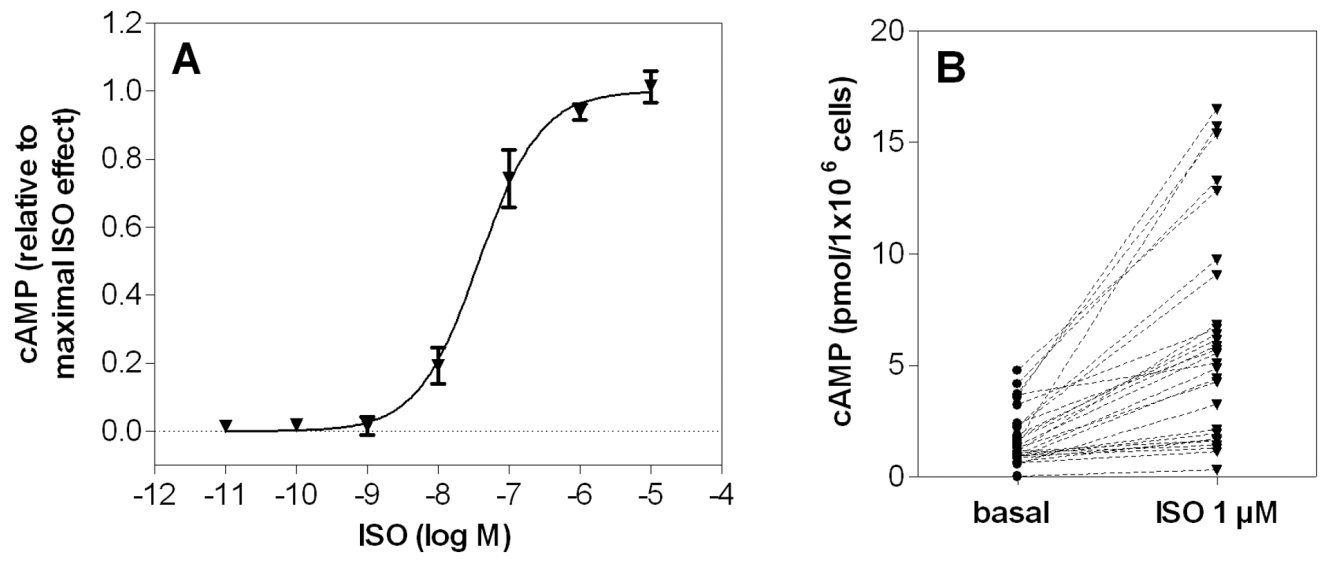

Figure 2. Measurement of CAMP content in neutrophil granulocytes (CAMP assay). cAMP accumulation in human neutrophil granulocytes $\left(5 \times 10^{5}\right.$ cells per sample) was monitored by HPLC-MS/MS system as described under Materials and Methods. (A) Concentration-response curve for ISO in the CAMP assay. Data shown are from four independent experiments, performed in triplicate (data points are mean \pm S.E.M.). The maximal ISOinduced CAMP production was set to 1.00. Data were analyzed by non-linear regression and were best fitted to sigmoidal concentration/response curve. (B) Inter-experimental variability of basal CAMP concentration in neutrophil granulocytes (basal) and cAMP level after stimulation with $1 \mu M$ ISO (ISO $1 \mu \mathrm{M}$ ). Each data point represents one independent experiment. cAMP levels after stimulation with ISO increased by $30-1000 \%$ relative to basal cAMP levels.

doi:10.1371/journal.pone.0064556.g002

\section{CAMP Accumulation and Extraction from Neutrophils (cAMP Assay)}

Reactions were conducted in triplicate in $1.5 \mathrm{ml}$ Eppendorf reaction vessels in a total volume of $100 \mu$ l. Fifty $\mu$ l of the reaction mixture containing $\mathrm{CaCl}_{2}(1 \mathrm{mM}$ final concentration after addition of neutrophils), IBMX (non-selective phosphodiesterase inhibitor; $100 \mu \mathrm{M}$ ) and the respective ligand at different concentrations in $1 \times$ DPBS were pre-incubated for $5 \mathrm{~min}$ at $37^{\circ} \mathrm{C}$. Isolated neutrophils suspended in $1 \times$ DPBS were pre-incubated separately for $10 \mathrm{~min}$ at $37^{\circ} \mathrm{C}$. Following the addition of $50 \mu \mathrm{l}$ of neutrophils $\left(5 \times 10^{5}\right.$ cells/reaction vessel $)$ to reaction mixture, samples were incubated for $10 \mathrm{~min}$ at $37^{\circ} \mathrm{C}$. Afterwards, samples were incubated for $10 \mathrm{~min}$ at $95^{\circ} \mathrm{C}$ in order to denature cell proteins and then cooled to $4^{\circ} \mathrm{C}$. One hundred $\mu \mathrm{l}$ of ice-cold internal standard (tenofovir; $100 \mathrm{ng} / \mathrm{ml}$ ) in eluent $\mathrm{A}$ (3/ $97 \mathrm{MeOH} / \mathrm{H}_{2} \mathrm{O}, 50 \mathrm{mM} \mathrm{NH} \mathrm{NAc}_{4} \mathrm{O}, 0.1 \% \mathrm{HOAc}$ ) were added. The suspension was centrifuged at $20.800 \times \mathrm{g}$ at $4^{\circ} \mathrm{C}$ for $5 \mathrm{~min}$ in order to remove denatured proteins. The cAMP concentration of the supernatant was determined by reversed phase HPLC coupled to mass spectrometry (HPLC-MS/MS).

\section{Quantitation of CAMP by HPLC-MS/MS}

In this study, cAMP levels were determined by HPLC-MS/ MS which is characterized by extremely high sensitivity and specificity [41-42]. Since this method is not yet commonly known and used, we describe the experimental protocol in some detail. The chromatographic separation was performed on an Agilent 1100 Series HPLC System (Agilent Technologies, Santa Clara, CA, USA) equipped with a binary pump system and with a $100 \mu \mathrm{l}$ sample loop. A combination of Supelco Column Saver $(2.0 \mu \mathrm{m}$ filter, Supelco Analytical, Bellafonte, CA, USA), Security Guard Cartridge $(\mathrm{C} 18,4 \times 2 \mathrm{~mm})$ in an Analytical Guard Holder KJO-4282 (Phenomenex, Aschaffenburg, Germany) and an analytical Zorbax Eclipse XDB-C16 column $(50 \times 4.6 \mathrm{~mm}, \quad 1.8 \mu \mathrm{m}$ particle size, Agilent Technologies), temperature controlled by a HPLC column oven at $25^{\circ} \mathrm{C}$, were used. The binary pump system supplied eluent A $(50 \mathrm{mM}$ ammonium acetate and $0.1 \%(\mathrm{v} / \mathrm{v})$ acetic acid in a methanol/ water mixture $(3 / 97(\mathrm{v} / \mathrm{v}))$ and eluent $\mathrm{B}(50 \mathrm{mM}$ ammonium acetate and $0.1 \%(\mathrm{v} / \mathrm{v})$ acetic acid in a methanol/water mixture $(97 / 3(\mathrm{v} / \mathrm{v}))$. The injection volume was $50 \mu \mathrm{l}$ and the flow rate of $0.4 \mathrm{ml} / \mathrm{min}$ remained constant throughout the chromatographic run. From 0 to $5 \mathrm{~min}$, the gradient of eluent B was linearly increased from 0 to $50 \%$ of eluent $\mathrm{B}$, and reequilibrium of the column to $100 \%$ of eluent A was achieved from 5 to $8 \mathrm{~min}$. Retention times of the analyte cAMP and the internal standard tenofovir were 6.2 and $5.4 \mathrm{~min}$, respectively. The internal standard was used to mathematically correct the loss of cAMP during preparation as well as possible variabilities in HPLC-MS/MS measurement. Analyte detection was conducted on an AB Sciex QTRAP 5500 triple quadrupole mass spectrometer (AB Sciex, Foster City, CA, USA) using selected reaction monitoring (SRM) analysis in positive ionization mode. For this purpose nitrogen was used as collision gas. Using a $50 \mathrm{~ms}$ dwell time, SRM transitions were monitored as follows: cAMP +330/136 and +330/312, tenofovir $+288 / 176$ and $+288 / 159$. The transition $+330 / 136$ was the most intense transition of cAMP and therefore used for quantification. Additionally the $+330 / 312$ transition of cAMP was used as qualifier. The transition $+288 / 176$ of tenofovir was used as quantifier and the transition $+288 / 159$ as qualifier. The mass spectrometer parameters were as follows: ion source voltage: $4500 \mathrm{~V}$, ion source temperature: $600^{\circ} \mathrm{C}$, curtain gas: 30 psi and collision gas: 9 psi. cAMP in samples was quantified by applying the standard curve, obtained by analysis of known amounts of pure cAMP at: 0.0262, 0.066, 0.164, 0.41, 1.024, 2.56, 6.4, 16, 40, 100, $250 \mathrm{pmol} /$ tube.

\section{Miscellaneous (Data Analysis, Statistical Analysis and GTPase Assay)}

Chromatograms, obtained by the HPLC-MS/MS analysis, were analyzed with the Analyst Software 1.5.1 (AB Sciex). Steady-state GTPase activity assay, using membrane preparations of Sf9 insect cells, expressing fusion protein $\beta_{2} A R-G_{s} \alpha$, was performed as described previously [43]. Data from the $\mathrm{O}_{2}{ }^{--}$, cAMP and GTPase assays were analyzed with the Prism 5.01 software (GraphPad, San Diego, CA, USA). The means \pm S.E.M. were always determined by the analysis of at least three 

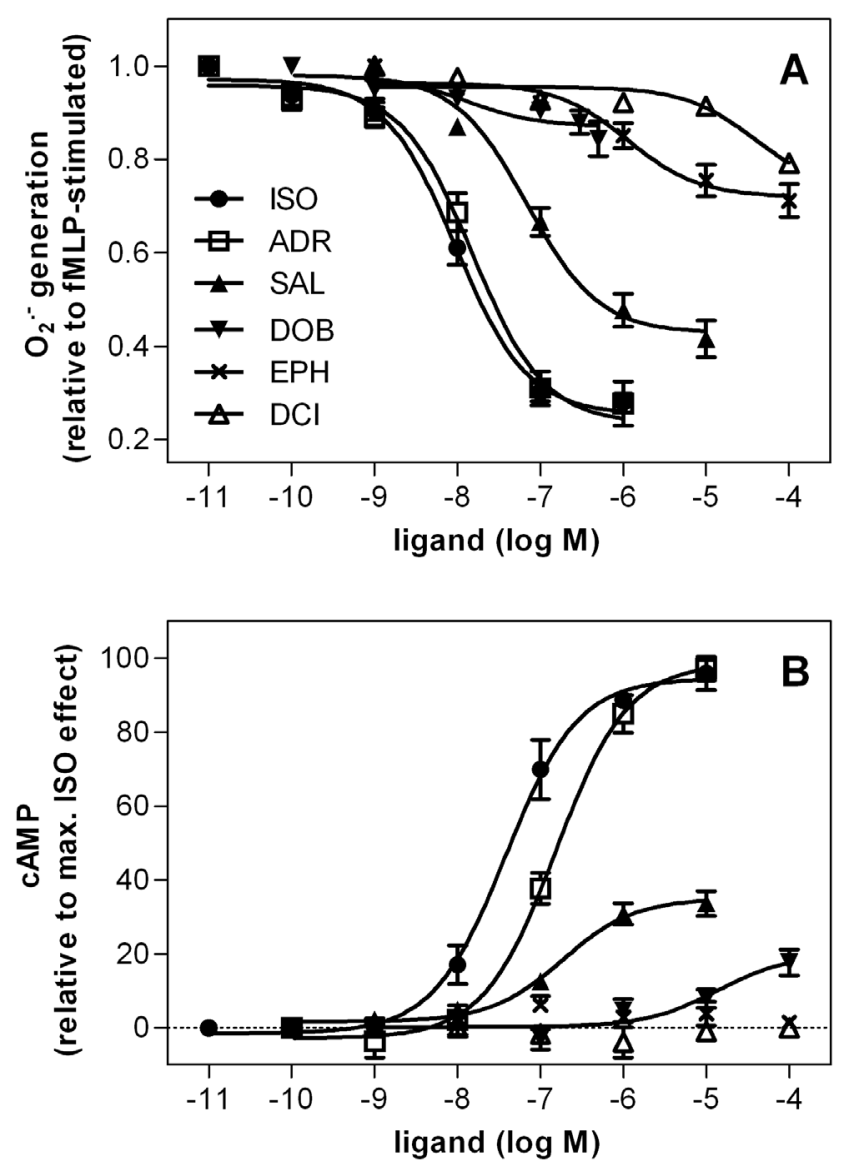

Figure 3. Concentration-response curves for $\beta_{2} A R$ agonists determined in the $\mathrm{O}_{2}{ }^{\cdot-}$ assay (A) and cAMP assay (B). The $\mathrm{O}_{2}{ }^{\cdot-}$ assay $\left(1 \times 10^{5}\right.$ cells per well) and the cAMP assay $\left(5 \times 10^{5}\right.$ cells per cup) were performed as described in Materials and Methods. Data were analyzed by non-linear regression and were best fitted to sigmoidal concentration/response curves. Data shown are the means \pm S.E.M. of four to nine independent experiments performed in triplicate. As DOB at concentrations higher than $500 \mathrm{nM}$ caused reduction of ferricytochrome c per se, the maximal DOB concentration examined in the $\mathrm{O}_{2}{ }^{--}$ assay was $500 \mathrm{nM}$.

doi:10.1371/journal.pone.0064556.g003

independent experiments, performed in triplicate, if not indicated otherwise.

The efficacy $\left(E_{\max }\right)$ of ISO in each assay was set to 1.00 and the efficacies of other ligands were referred to this value. The $\mathrm{p} K_{\mathrm{B}}$ values for $\beta_{2} \mathrm{AR}$ antagonists were calculated according to Cheng and Prusoff [44] using the following equation: $\mathrm{p} K_{\mathrm{B}}=-\log \left(\mathrm{IC}_{50 \text { anta- }}\right.$ gonist $\left./\left(1+\left(\mathrm{c}_{I S O} / \mathrm{x}\right)\right)\right) ; \mathrm{IC}_{50 \text { antagonist }}-\mathrm{IC}_{50}$ value of an antagonist, determined in antagonist mode, $\mathrm{c}_{I S O}$ - used concentration of ISO, $\times-\mathrm{IC}_{50}\left(\mathrm{O}_{2}{ }^{--}\right.$assay) or $\mathrm{EC}_{50}$ value (cAMP assay and GTPase assay) for ISO, determined in agonist mode (data from Table 1).

Data for receptor ligands were analyzed using one-way ANOVA, followed by Bonferroni's multiple comparison test, in order to compare $\mathrm{p} K_{\mathrm{B}}$ values of the examined $\beta_{2} \mathrm{AR}$ antagonists between the $\mathrm{O}_{2}{ }^{-}$, cAMP and GTPase assay. Data for AC- and PKA inhibitors were analyzed using one-way ANOVA, followed by Dunnett's multiple comparison test. Statistical significance was defined as $\mathrm{p}<0.05$ (95\% confidence interval).

\section{Results}

Characterization of the $\beta_{2} A R$ on Human Neutrophils with $\beta_{2}$ AR Agonists

$\beta_{2} \mathrm{AR}$ agonists with efficacies varying from very weak partial to full agonism [45] were examined. The effects of $\beta_{2} \mathrm{AR}$ agonists were measured as inhibition of fMLP-stimulated $\mathrm{O}_{2}{ }^{--}$production (Fig. 1) and as cAMP accumulation (Fig. 2). In both cases, the inter-experimental variability was high (Figs. 1 and 2). Note that in Figs. $1 \mathrm{C}$ and 2B, data from different individuals are depicted. High inter-individual variability of human neutrophil function was observed previously [46]. However, when neutrophils from a given donor were analyzed on different days, data in the two test systems generally varied by less than $20 \%$ (data not shown). Thus, interindividual data variability is a much greater issue with neutrophils than intraindividual day-to-day variability. Accordingly, in order to allow comparison of results from experiments with different donors in this study, data were normalized with 1.00 representing the maximal effect of the $\beta_{2} \mathrm{AR}$ agonist ISO and 0.00 representing the basal activity.

Potencies and efficacies of the examined $\beta_{2} \mathrm{AR}$ agonists in the $\mathrm{O}_{2}{ }^{--}$and the cAMP assay are listed in Table 1 and concentrationresponse curves are depicted in Fig. 3. Additionally, the $\mathrm{EC}_{50}$ and $E_{\max }$ values of ligands determined in steady-state GTPase activity assays using membrane preparations of Sf9 insect cells expressing the $\beta_{2} A R-G_{s \alpha S}$ fusion protein $[43,45]$ are listed in Table 1 . The $\beta_{2} \mathrm{AR}-\mathrm{G}_{\mathrm{s} \alpha \mathrm{S}}$ fusion protein is artificial but has become a standard system for the pharmacological analysis of the $\beta_{2} \mathrm{AR}[43,45]$. For a detailed discussion on the advantages and disadvantages of the fusion protein technique as well as additional references relevant for this approach, the reader is referred to ref. 43. Potencies of ISO, ADR and SAL were higher in the $\mathrm{O}_{2}{ }^{-}$assay than in the cAMP assay. EPH and DCI were lacking agonistic activity in the cAMP assay at concentrations up to $100 \mu \mathrm{M}$, whereas inhibitory effects of both ligands on fMLP-stimulated $\mathrm{O}_{2}{ }^{-{ }^{-}}$production were readily observed. The efficacy of ADR was comparable in both test systems, but the efficacy of SAL more than two times higher in the $\mathrm{O}_{2}{ }^{--}$assay relative to the cAMP assay. When the data from the recombinant test system were included in the comparison, the rank order of potency of ligands was cAMP assay $<$ GTPase assay $<\mathrm{O}_{2}{ }^{--}$assay, and the rank order of efficacy was cAMP assay $<\mathrm{O}_{2}{ }^{--}$assay $\approx$ GTPase assay (Fig. 4).

In case of the two-state model postulating a single active state, we would have expected linear correlations for agonists with respect to efficacies and potencies, regardless of which parameters are compared. However, Fig. 4 shows that the correlations are, in general, rather poor, regardless of which comparisons are being made. The worst correlations in terms of deviation from the theoretically expected slope of 1.00 in case of identity of parameters were observed for the comparison of $\mathrm{pEC}_{50}$ values in the GTPase and $\mathrm{O}_{2}{ }^{-}$assay (Fig. $4 \mathrm{~B}$ ) and $\mathrm{pEC}_{50}$ values in the GTPase and cAMP assay (Fig. 4G). A limitation of our study is that we studied only a limited number of agonists, but an advantage is that the ligands cover a broad range of efficacies and potencies so that clustering of the data in one spot is avoided. In fact, this type of two-dimensional comparison of ligand potencies and efficacies has been repeatedly used to support the concept of ligand-specific receptor conformations in various test systems $[24,27,32,40]$.

A trivial explanation for the differing effects of $\beta_{2} \mathrm{AR}$ agonists in the $\mathrm{O}_{2}{ }^{--}$assay and cAMP assay could be that the agonists exhibit $\mathrm{O}_{2}{ }^{\cdot-}$ scavenging properties on fMLP-stimulated $\mathrm{O}_{2}{ }^{--}$production. However, when $\mathrm{O}_{2}{ }^{--}$production in neutrophils was triggered with phorbol-12-myristate-13-acetate (activator of protein kinase $\mathrm{C}$, 

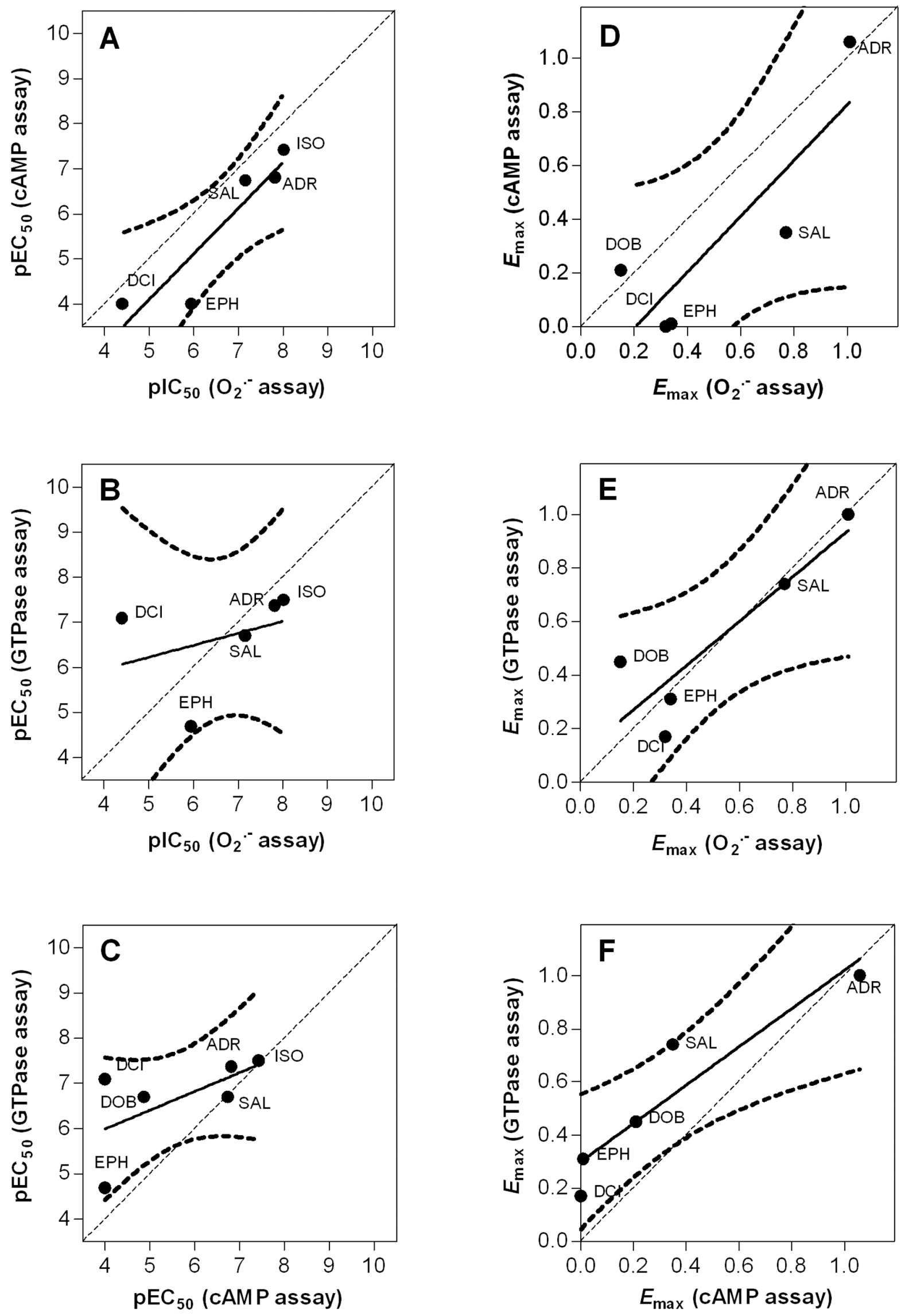
Figure 4. Pair-wise comparison of the potencies (A-C) and efficacies (D-F) of the $\beta_{2} A R$ agonists in the $\mathrm{O}_{2}{ }^{\cdot-}$ assay, the cAMP assay and the GTPase assay. The data for comparison were taken from Table 1 and were analyzed by linear regression. The dashed lines represent the $95 \%$ confidence intervals in the regression line. The diagonal dotted line indicates a theoretical line for identical values $($ slope $=1)$. Slopes $(95 \%$ confidence interval) and $r^{2}$ of the calculated correlations are as follows; A. $1.02(0.22$ to 1.81$), 0.85 ; \mathbf{B} .0 .27(-1.05$ to 1.58$), 0.12 ; \mathbf{C}$. $0.42(-0.32$ to 1.15), 0.38 ; D. 1.04 ( -0.14 to 2.21 ), 0.73 ; E. 0.83 (0.02 to 1.63$)$, 0.78 ; F. 0.72 (0.22 to 1.22$), 0.89$. doi:10.1371/journal.pone.0064556.g004

$100 \mathrm{nM}$ ) instead of fMLP, the examined $\beta_{2} \mathrm{AR}$ agonists had no effect on $\mathrm{O}_{2}^{\cdot-}$ production at all (data not shown).

\section{Characterization of the $\beta_{2} A R$ on Human Neutrophils with $\beta_{2}$ AR Antagonists}

According to conventional models of GPCR activation, potency of an antagonist for a given receptor is constant irrespective of the tissue or recombinant system selected for the characterization, the agonist used for the stimulation of GPCR and downstream signaling event monitored [20-22,47]. However, by monitoring the cAMP accumulation and cAMP response element-mediated reporter gene transcription in Chinese hamster ovary (CHO) cells, different $K_{\mathrm{B}}$ values were determined for $\beta_{2} \mathrm{AR}$ antagonists [48]. These data indicate that antagonists, like agonists, may stabilize functionally distinct receptor conformations. Likewise, we obtained evidence for functional selectivity of antagonists at various recombinant histamine receptor subtypes [49]. Hence, the question arose whether parameter-dependent $\beta_{2} \mathrm{AR}$ antagonist potency is also apparent in a native test system, namely in neutrophils.

The $\mathrm{p} K_{\mathrm{B}}$ values for ICI, MET, ALP, BIS and ATE were determined in the cAMP and $\mathrm{O}_{2}{ }^{-}$assay by applying a submaximally effective concentration of ISO and increasing concentrations of $\beta_{2} \mathrm{AR}$ antagonists. Concentration-response curves for antagonists are shown in Fig. 5. In Table 2, the results are summarized and compared with antagonistic activity of the same ligands in the recombinant test system (GTPase assay using membranes of Sf9 insect cells expressing $\left.\beta_{2} \mathrm{AR}-\mathrm{G}_{\mathrm{s} \alpha \mathrm{S}}\right)$. The statistical analysis of the obtained data revealed no difference of $\mathrm{p} K_{\mathrm{B}}$ values between the two different parameters in neutrophils, BIS being an exception. However, in comparison with data on neutrophils, the potencies of all antagonists were significantly reduced on the recombinantly expressed $\beta_{2} A R-G_{s} \alpha$ s. Fig. 6 shows correlations of the $\mathrm{p} K_{\mathrm{B}}$ values of antagonists for the various parameters analyzed. It is evident that the correlations for antagonists are much better than the corresponding correlations for agonists shown in Fig. 5.

\section{Do AC- and PKA-activation Interfere with fMLP-} stimulated $\mathrm{O}_{2}^{\cdot-}$ Production?

As already mentioned in the introduction, $\beta_{2} \mathrm{AR}$-signaling is very complex, depending on ligand and test system $[15,16,18,26,27]$. $\beta_{2}$ AR-mediated inhibition of fMLP-stimulated $\mathrm{O}_{2}{ }^{-}$production is thought to be due to cAMP production and PKA activation [50-51]. In order to address this question we studied the effects of three structurally distinct and well-established PKA inhibitors. Among the inhibitors are an isoquinoline sulfonamide [52], a cAMP analog [53] and a microbial metabolite [54]. However, in our experiments, we failed to obtain evidence for the hypothesis that activation of PKA after $\beta_{2} \mathrm{AR}$ stimulation is a crucial event for inhibition of fMLP-stimulated $\mathrm{O}_{2}{ }^{--}$production (Fig. 7). Specifically, compounds H89 and KT5720, widely-used and effective cell-permeable competitive inhibitors of the ATPbinding to the ATP-binding pocket of the PKA in other test systems [55-58], did not reverse ISO-induced inhibition of fMLPstimulated $\mathrm{O}_{2}{ }^{--}$production (also when neutrophils were pretreated 15 min with H89 or KT5720). Even the cAMP antagonist RpcAMPS which competes with cAMP for the binding to the regulatory subunits of PKA [57,59], did not interfere with the effect of ISO of $\mathrm{O}_{2}{ }^{--}$production in human neutrophils (Fig. 7).

Moreover, we tried to assess the involvement of the cAMP signaling pathway in the fMLP-stimulated $\mathrm{O}_{2}{ }^{--}$production by applying the AC inhibitor SQ 22536 [60]. Surprisingly, SQ 22536 enhanced rather than diminished the inhibitory effect of ISO on fMLP-induced $\mathrm{O}_{2}{ }^{\cdot-}$ production (Fig. 8A). Additionally, SQ 22536 exhibited unexpected inhibitory effects on fMLP-induced $\mathrm{O}_{2}{ }^{--}$ production on its own. SQ 22536 by itself did not increase cAMP levels in neutrophils, and the compound also did not inhibit the ISO-induced cAMP increase (Fig. 8B). Pleiotropic and AC-

Table 2. Comparison of $\mathrm{p} K_{\mathrm{B}}$ values of the $\beta_{2} \mathrm{AR}$ antagonists, determined in three different test systems.

\begin{tabular}{|c|c|c|c|}
\hline \multirow[t]{2}{*}{ Cpd. } & \multirow{2}{*}{$\begin{array}{l}\mathrm{O}_{2}{ }^{--} \text {assay }\left(\boldsymbol{\beta}_{2} \mathrm{AR} \text { on neutrophil }\right. \\
\text { granulocytes) } \\
\mathrm{p} K_{\mathrm{B}} \pm \text { S.E.M. }\left(K_{B} \text { in } \mu \mathrm{M}\right)\end{array}$} & \multirow{2}{*}{$\begin{array}{l}\text { CAMP assay }\left(\beta_{2} A R \text { on neutrophil }\right. \\
\text { granulocytes) } \\
\text { p } K_{\mathrm{B}} \pm \text { S.E.M. }\left(K_{B} \text { in } \mu M\right)\end{array}$} & \multirow{2}{*}{$\begin{array}{l}\text { GTPase assay (recombinant protein } \\
\beta_{2} \text { AR-G } \\
\left.\text { p } K_{\mathrm{B}} \pm \text { S.E. }\right)^{\mathrm{a}}\end{array}$} \\
\hline & & & \\
\hline ICI & $9.51 \pm 0.09(0.00031)$ & $9.97 \pm 0.07(0.00011)$ & $8.55 \pm 0.14^{* *,+,++}(0.0028)$ \\
\hline MET & $7.18 \pm 0.15(0.066)$ & $7.19 \pm 0.12(0.065)$ & $6.08 \pm 0.17^{* *,++}(0.83)$ \\
\hline ALP & $9.40 \pm 0.10(0.00040)$ & $9.71 \pm 0.06(0.00020)$ & $8.56 \pm 0.14^{* *,+1+}(0.0028)$ \\
\hline BIS & $6.58 \pm 0.19(0.26)$ & $7.17 \pm 0.11 *(0.068)$ & $5.77 \pm 0.10^{* *,+++}(1.70)$ \\
\hline ATE & $5.89 \pm 0.12(1.29)$ & $5.99 \pm 0.20(1.02)$ & $5.12 \pm 0.17^{*,+}(7.59)$ \\
\hline
\end{tabular}

On human neutrophil granulocytes, the $\mathrm{O}_{2}^{--}$assay $\left(1 \times 10^{5}\right.$ cells per well) and the cAMP assay $\left(5 \times 10^{5}\right.$ cells per sample) were performed as described under Materials and Methods. Steady-state GTPase activity assay, using membrane preparations of Sf9 insect cells, expressing fusion protein $\beta_{2} A R-G_{s} \alpha s$, was performed as described in [43]. $\mathrm{O}_{2}{ }^{--}$and cAMP production as well as GTP hydrolysis were determined at submaximally effective concentration of ISO (100 nM in the $\mathrm{O}_{2}{ }^{--}$and cAMP assay, 10 nM in the GTPase assay) in the presence of increasing concentrations of $\beta_{2} A R$ antagonists. Data were analyzed by non-linear regression and were best fitted to sigmoidal concentration/response curves. Data shown are from four to five independent experiments performed in triplicate. The pK $K_{B}$ values were calculated from the $I_{50}$ values according to Cheng and Prusoff [44]. $\mathrm{p} K_{\mathrm{B}}$ values were compared with each other using one-way ANOVA, followed by Bonferroni's multiple comparison test ( $\mathrm{p} K_{\mathrm{B}}$ significantly different to: ${ }^{*} \mathrm{O}_{2}{ }^{--}$assay, ${ }^{+}$cAMP assay; one symbol: $\mathrm{p}<0.05$, two symbols: $\mathrm{p}<0.01$, three symbols: $\left.\mathrm{p}<0.001\right)$. Non-logarithmic $K_{\mathrm{B}}$ values in $\mu \mathrm{M}$ are shown in parentheses.

doi:10.1371/journal.pone.0064556.t002 

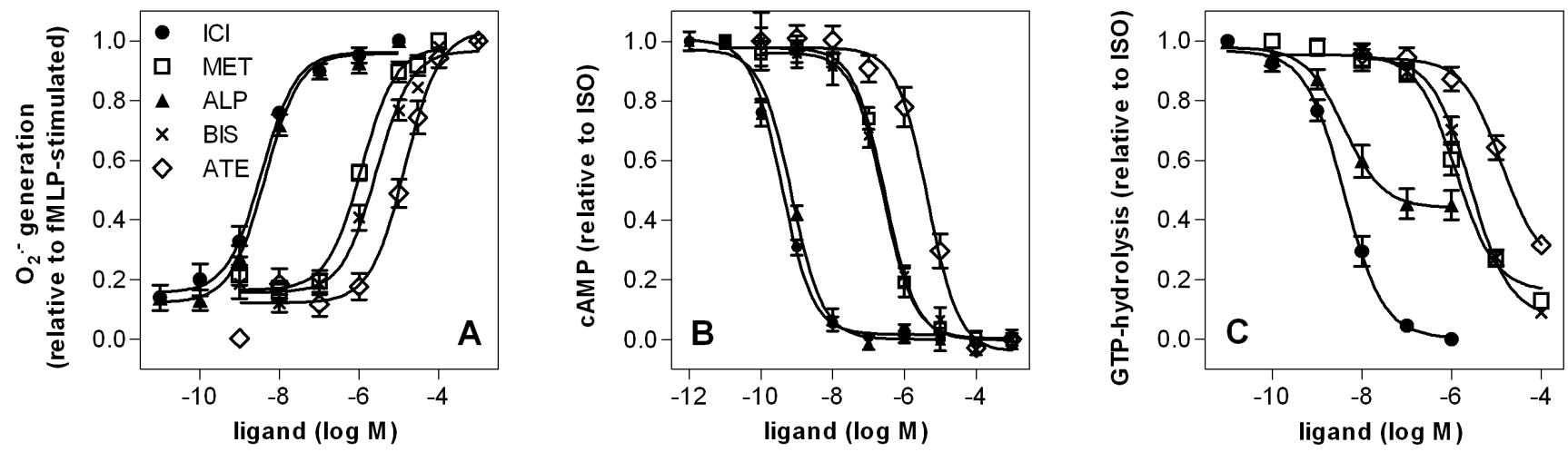

Figure 5. Concentration-response curves for $\beta_{2} A R$ antagonists determined in the $\mathrm{O}_{2}{ }^{-{ }^{-}}$(A), cAMP (B) and GTPase assay (C). The $\mathrm{O}_{2}{ }^{-{ }^{-}}$ assay $\left(1 \times 10^{5}\right.$ cells per well) and the cAMP assay $\left(5 \times 10^{5}\right.$ cells per cup) were performed as described in sections 2.3 and 2.4 , respectively. Steady-state GTPase activity assay, using membrane preparations of Sf9 insect cells, expressing fusion protein $\beta_{2} A R-G_{s \alpha s}$, was performed as described in [43]. Data were analyzed by non-linear regression and were best fitted to sigmoidal concentration/response curves. Data shown are the means \pm S.E.M. of four to five independent experiments performed in triplicate. $\mathrm{O}_{2}{ }^{--}$and CAMP production as well as GTP hydrolysis were determined at submaximally effective concentration of ISO (100 nM in the $\mathrm{O}_{2}{ }^{--}$and cAMP assay, $10 \mathrm{nM}$ in the GTPase assay) in the presence of increasing concentrations of $\beta_{2} \mathrm{AR}$ antagonists.

doi:10.1371/journal.pone.0064556.g005

independent effects of SQ 22536 have been observed repeatedly [61].

As an additional tool we examined the diterpene, FSK, a direct activator of membranous ACs [61]. However, FSK did neither significantly reduce fMLP-stimulated $\mathrm{O}_{2}{ }^{--}$production (Fig. 8A) nor robustly increase cAMP levels (Fig. 8B).

In order to provide proof of principle that an increase in intracellular cAMP concentration is capable of inhibiting fMLPstimulated $\mathrm{O}_{2}{ }^{--}$production, we examined the effects of cAMP and various cAMP analogs on NADPH oxidase activation. DB-cAMP is lipophilic and penetrates the plasma membrane. Inside the cell, DB-cAMP is converted to the biologically active 6-MB-cAMP [62]. In accordance with previous data [9], DB-cAMP reduced fMLP-stimulated $\mathrm{O}_{2}{ }^{--}$production, whereas the control compound sodium butyrate was ineffective (Fig. 9). In addition, the monobutyrylated control compound 6-MB-cAMP did not robustly inhibit NADPH oxidase, most likely due to inefficient membrane penetration. Sp-cAMPS is less lipophilic than DB-cAMP but does not require bioactivation [59]. Sp-cAMPS was similarly effective at inhibiting $\mathrm{O}_{2}{ }^{--}$production as DB-cAMP. These data show that cAMP does have the potential to inhibit NADPH oxidase. However, we also noted that very high concentrations of DBcAMP are required to elicit inhibition, probably exceeding the intracellular cAMP concentrations achieved following $\beta_{2} \mathrm{AR}$ stimulation.

cAMP itself also slightly inhibited $\mathrm{O}_{2}{ }^{--}$production. This could be due to extracellular degradation of cAMP to adenosine by phosphodiesterases and ectonucleotidases and subsequent activation of adenosine A2-receptors by adenosine [63]. Import of cAMP via multidrug resistance protein transporters (MRPs) into cells and subsequent PKA activation could be involved as well [64]. Likewise, the small inhibitory effects of the PKA inhibitor Rp-cAMPS could be due to adenosine liberation from the parent compound. We do not have a satisfactory explanation for the small but significant stimulatory effect of the mono-butyrylated control compound $2^{\prime}-\mathrm{O}-\mathrm{MB}-\mathrm{cAMP}$ on $\mathrm{O}_{2}{ }^{--}$production. However, we confirmed that the compound per se did not activate $\mathrm{O}_{2}{ }^{--}$ production or reduced ferricytochrome $\mathrm{c}$ independently of NADPH oxidase (data not shown). The activator of the cAMP effector protein Epac, 8-pCPT-2'-O-Me-cAMP [65], did not inhibit fMLP-induced $\mathrm{O}_{2}^{--}$production, arguing against an involvement of Epac in NADPH oxidase regulation. We also observed that the PKA inhibitors H89, KT5720 and Rp-cAMPS showed no reversing effect on the inhibition of $\mathrm{O}_{2}{ }^{-}$production caused by DB-cAMP (Fig. 7). These data raise questions whether a hitherto unidentified cAMP-binding protein is involved in the inhibition of $\mathrm{O}_{2}{ }^{--}$production by DB-cAMP and Sp-cAMPS.

\section{Discussion}

The two-state model of receptor activation implying an active $\left(\mathrm{R}^{*}\right)$ and an inactive $(\mathrm{R})$ state has now been superseded by a more complex model involving multiple active receptor conformations that lead to ligand-specific receptor activation, also referred to as functional selectivity or biased agonism [19-33]. Functional selectivity has been reported for numerous GPCRs such as dopamine $\mathrm{D}_{1}$ and $\mathrm{D}_{2}$ receptors, the histamine $\mathrm{H}_{2}$ and $\mathrm{H}_{4}$ receptor, adenosine $A_{1}$ and $A_{3}$ receptors, the $\alpha_{2 A}$-adrenoceptor and the $\beta_{2} \mathrm{AR}[15-33,40,49]$. So-called biased ligands can differently activate $\mathrm{G}$ protein-dependent and -independent signaling such as the $\beta$-arrestin pathway $[27,32,34,35]$, can discriminate between $G_{s}, G_{i}, G_{q}$ and other $G$ protein-mediated pathways $[15,66]$ or even selectively modulate e.g. $G_{i 1}, G_{i 2}$ and $G_{i 3}$ protein subtype activities [67]. Therefore, it is not surprising that any given ligand possesses multiple potencies and efficacies depending on the down-stream pathway analyzed [33]. This concept was also confirmed in our study with $\beta_{2} \mathrm{AR}$ agonists in human neutrophils using the cAMP assay and the $\mathrm{O}_{2}{ }^{--}$assay as parameters and by comparison of the results with literature data obtained in recombinant test system (Fig. 4). If only a single active $\beta_{2} \mathrm{AR}$ conformation existed, we would have expected linear correlations following the dotted lines in Fig. 4 between potencies and efficacies (relative to the reference compound ISO) of agonists, regardless of which parameters are considered. However, this was not the case. In accordance with our data, fluorescence studies with purified $\beta_{2} \mathrm{AR}$ nuclear magnetic resonance studies provided evidence for ligand-specific conformations [31,37,39].

With respect to $\beta_{2} \mathrm{AR}$ antagonists, effects were similar in the cAMP and $\mathrm{O}_{2}{ }^{\cdot-}$ assay on neutrophils (Table 2 and Fig. 5), indicating that in neutrophils, functional selectivity is predominantly observed for $\beta_{2} \mathrm{AR}$ agonists. In contrast to neutrophil parameters, potencies of antagonists were generally lower at the 

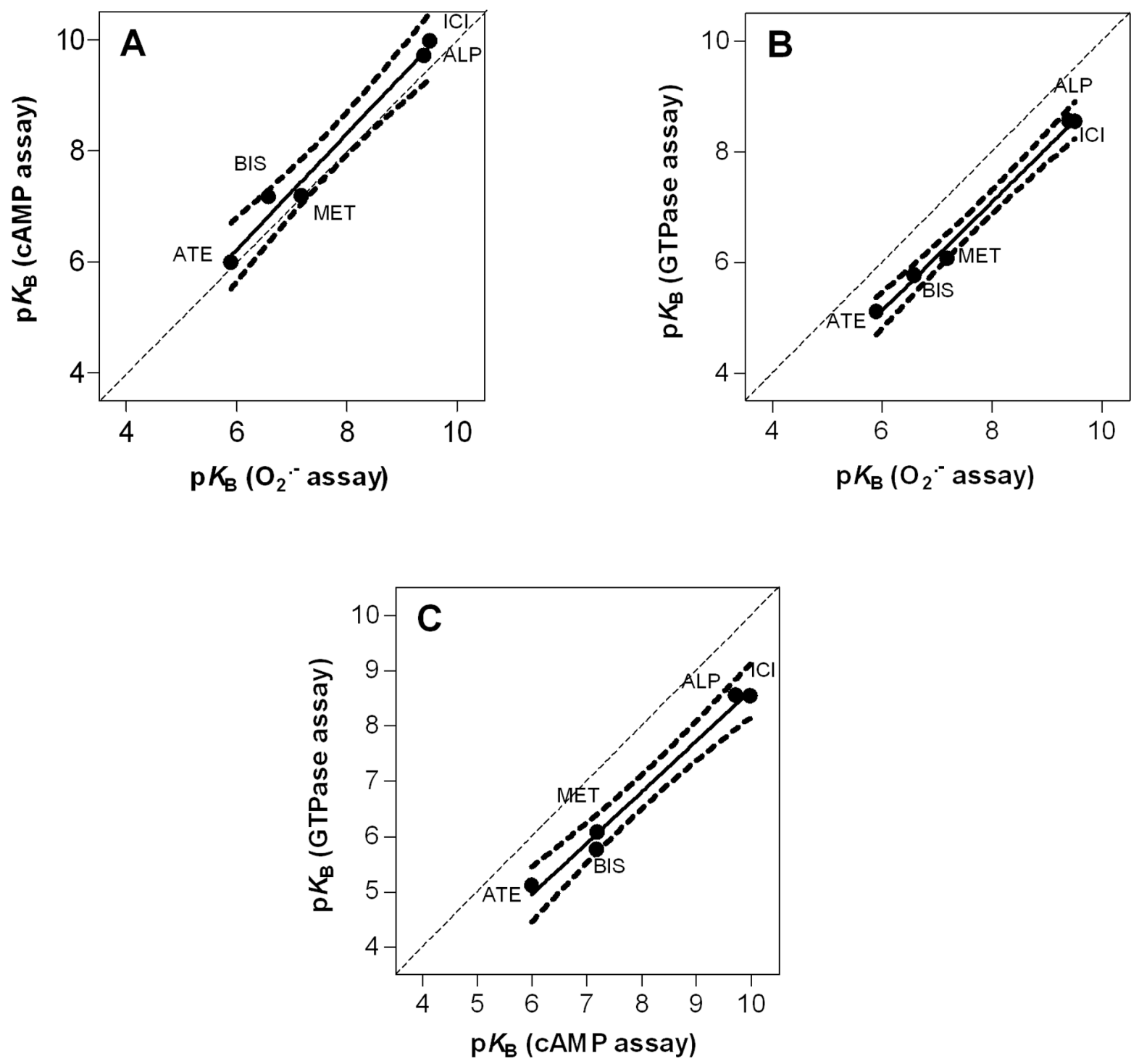

Figure 6. Pair-wise comparison of the $\mathrm{p} K_{\mathrm{B}}$ values of the $\beta_{2} \mathrm{AR}$ antagonists in the $\mathrm{O}_{2}{ }^{--}$assay, the cAMP assay and the GTPase assay. The data for comparison were taken from Table 2 and were analyzed by linear regression. The dashed lines represent the $95 \%$ confidence intervals in the regression line. The diagonal dotted line indicates a theoretical line for identical values (slope $=1)$. Slopes $\left(95 \%\right.$ confidence interval) and $r^{2}$ of the calculated correlations are as follows; A. 1.05 (0.79 to 1.30), 0.98; B. 0.98 (0.84 to 1.12), 0.99; C. 0.93 (0.73 to 1.12), 0.99.

doi:10.1371/journal.pone.0064556.g006

recombinant $\beta_{2} \mathrm{AR}$ than at the native $\beta_{2} \mathrm{AR}$ (Table 2), and there were also ligand-specific differences. The trend towards lower antagonist (inverse agonist) potencies at the recombinant $\beta_{2} \mathrm{AR}$ could be due to higher constitutive activity of the recombinant than of the native system [20].

The vast majority of reports about functional selectivity originate from studies with recombinant test systems or purified receptors (see, e.g., [31,34-36,38-39]). On the contrary, functional selectivity in native test systems has been rarely studied so far, e.g. for the histamine $\mathrm{H}_{4}$ receptor on isolated human eosinophils [68] and for the histamine $\mathrm{H}_{2}$ receptor on isolated human eosinophils and neutrophils [40]. Here, we report on functional selectivity of the $\beta_{2} \mathrm{AR}$ in human neutrophils. In accordance with our data, there is evidence for functional selectivity of $\beta_{2} \mathrm{AR}$ ligands in cardiomyocytes [69]. In this system, stereoisomers of fenoterol differentially activate $\mathrm{G}_{\mathrm{i}^{-}}$and $\mathrm{G}_{\mathrm{s}}$-proteins.
Unfortunately, in-depth analysis of functional selectivity in neutrophils is hampered by limited possibilities to block coupling of the $\beta_{2} \mathrm{AR}$ to coupling partners. GPCR-G $\mathrm{G}_{\mathrm{i}}$ protein coupling can be interrupted with pertussis toxin [70], whereas there is no pharmacological tool available for the selective inhibition of $G_{s}$ and $G_{q}$ coupling or the $\beta$-arrestin pathway in native test systems. Furthermore, since the formyl peptide receptor is coupled to $\mathrm{G}_{\mathrm{i}^{-}}$ proteins and an essential stimulatory component in the $\mathrm{O}_{2}{ }^{--}$assay, we could not use pertussis toxin to differentiate between $\beta_{2} \mathrm{AR}$ ligands in this assay and in the cAMP assay. Moreover, in neutrophils, difficulties for effective genetic manipulation, interindividual variability and relatively short life time impede with more detailed analysis of functional selectivity in this native test system.

Our data obtained by measuring GTP hydrolysis in the recombinant test system reflect coupling of the $\beta_{2} \mathrm{AR}$ solely to the short splice variant of the $\mathrm{G}_{\mathrm{s}}$ protein $[43,45]$. There is no 


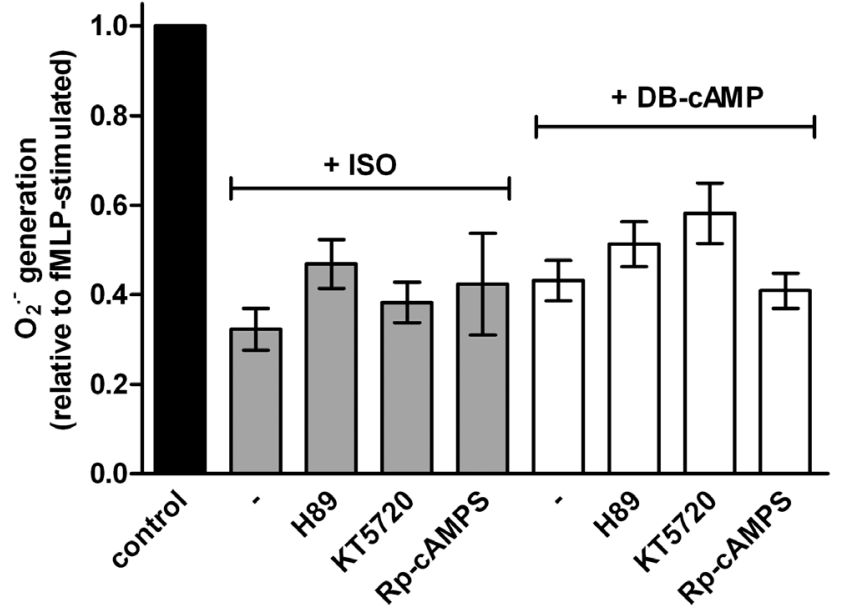

Figure 7. Effects of different PKA inhibitors on the ISO- and DBcAMP-induced inhibition of fMLP-stimulated $\mathrm{O}_{2}^{--}$production. $\mathrm{O}_{2}{ }^{--}$production in human neutrophil granulocytes $\left(1 \times 10^{5}\right.$ cells per well) was monitored by measuring the superoxide dismutase-inhibitable reduction of ferricytochrome $\mathrm{c}$ at $550 \mathrm{~nm}$. Data shown (mean \pm S.E.M.) are from three independent experiments, performed in triplicate. Concentrations used are as follows; ISO $100 \mathrm{nM}$, DB-CAMP $500 \mu \mathrm{M}, \mathrm{H} 89$ $1 \mu \mathrm{M}$, KT5720 $10 \mu \mathrm{M}$ and Rp-cAMPS $100 \mu \mathrm{M}$. H89, KT5720 and RpcAMPS had no significant reversal effect on the inhibitions caused by ISO and DB-CAMP.

doi:10.1371/journal.pone.0064556.g007

doubt that the $\beta_{2} \mathrm{AR}$ couples to $\mathrm{G}_{\mathrm{s}}$ in neutrophils, but no information is available regarding the involvement of specific $G_{s}$ splice variants. The question remains what the reason for the generally increased potency of the examined $\beta_{2} \mathrm{AR}$ agonists in the $\mathrm{O}_{2}{ }^{--}$assay compared to the cAMP assay is. Lack of correlation between the cAMP accumulation and inhibition of fMLP-induced
$\mathrm{O}_{2}{ }^{--}$production in neutrophils has been described also by other research groups using other stimuli [71-74]. Among other reasons, better coupling efficiency of the $\beta_{2} \mathrm{AR}$ to the $\mathrm{O}_{2}{ }^{--}$pathway than to the cAMP pathway is of relevance for the divergence in data. Differences in strength of coupling to different signaling pathways have been reported for other receptors [75]. Additionally, we have no evidence for the involvement of Epac in the signal transduction pathway of the $\beta_{2} \mathrm{AR}$ leading to inhibition of NADPH oxidase since an effective Epac activator failed to inhibit fMLP-stimulated $\mathrm{O}_{2}{ }^{-}$production (Fig. 9).

We failed to support an involvement of AC, cAMP and PKA in $\beta_{2}$ AR-mediated inhibition of fMLP-stimulated $\mathrm{O}_{2}{ }^{--}$production. Thus, it appears that the two measured events (cAMP accumulation and $\mathrm{O}_{2}{ }^{--}$production) in neutrophils are independent of each other. The lack of effect of DCI and EPH on cAMP accumulation despite inhibitory effects of these ligands on $\mathrm{O}_{2}{ }^{-}$ production supports the concept of cAMP-independent inhibition of NADPH oxidase. Moreover, SAL is more effective at inhibiting NADPH oxidase than at increasing cAMP. Our failure to detect stimulatory effects of DCI and EPH on cAMP accumulation and ineffective stimulation of cAMP accumulation by SAL are not due to cAMP degradation since we included a phosphodiesterase inhibitor into the cAMP assay. Moreover, we applied a highly sensitive and specific MS method to detect cAMP, avoiding notorious cross-reactivity problems of antibodies widely applied in cyclic nucleotide detection $[41,42,76]$. Thus, our study addressing ligand-specific receptor conformations also casted doubt about the dogma of cAMP-dependent inhibition of NADPH oxidase by the $\beta_{2} \mathrm{AR}$ although, in principle, cAMP can inhibit $\mathrm{O}_{2}{ }^{--}$production (Fig. 9). Even in case of inhibition of $\mathrm{O}_{2}{ }^{--}$production by cAMP analogs, we failed to obtain positive evidence for an involvement of PKA (Fig. 7).

Analysis of the signaling pathways responsible for inhibition of $\mathrm{O}_{2}^{--}$production in neutrophils is hampered by unsuitability of
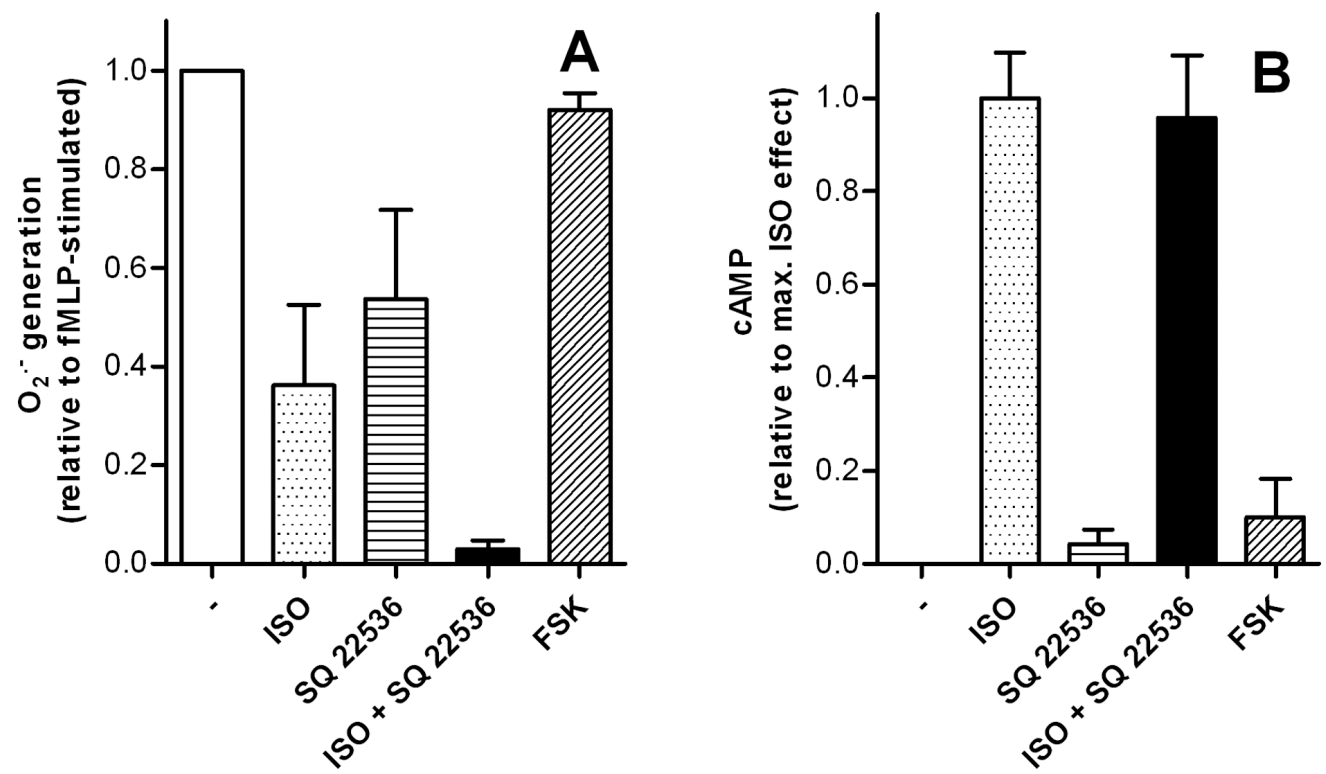

Figure 8. Effects of SQ 22536 and FSK on the fMLP-stimulated $\mathrm{O}_{2}{ }^{--}$production (A) and cAMP accumulation (B). The $\mathrm{O}_{2}{ }^{\cdot-}$ assay $\left(1 \times 10^{5}\right.$ cells per well) and the cAMP assay $\left(5 \times 10^{5}\right.$ cells per cup) were performed as described in Materials and Methods. Data shown (mean \pm S.E.M.) are from three to six independent experiments, performed in triplicate. Concentrations used are as follows; ISO $100 \mathrm{nM}$ (A) and $1 \mu \mathrm{M}$ (B), SQ $22536100 \mu \mathrm{M}$. For comparison, we also studied the effect of the direct AC activator FSK $(10 \mu \mathrm{M})$. In all tubes, a final concentration of $1 \%$ (v/v) DMSO (unavoidable for dissolving SQ 22536 and FSK) was present to achieve comparable results. SQ 22536 had no significant reversal effect on the inhibition caused by ISO in the $\mathrm{O}_{2}^{\cdot-}$ assay, and FSK had no significant inhibitory effect on fMLP stimulation in this assay.

doi:10.1371/journal.pone.0064556.g008 


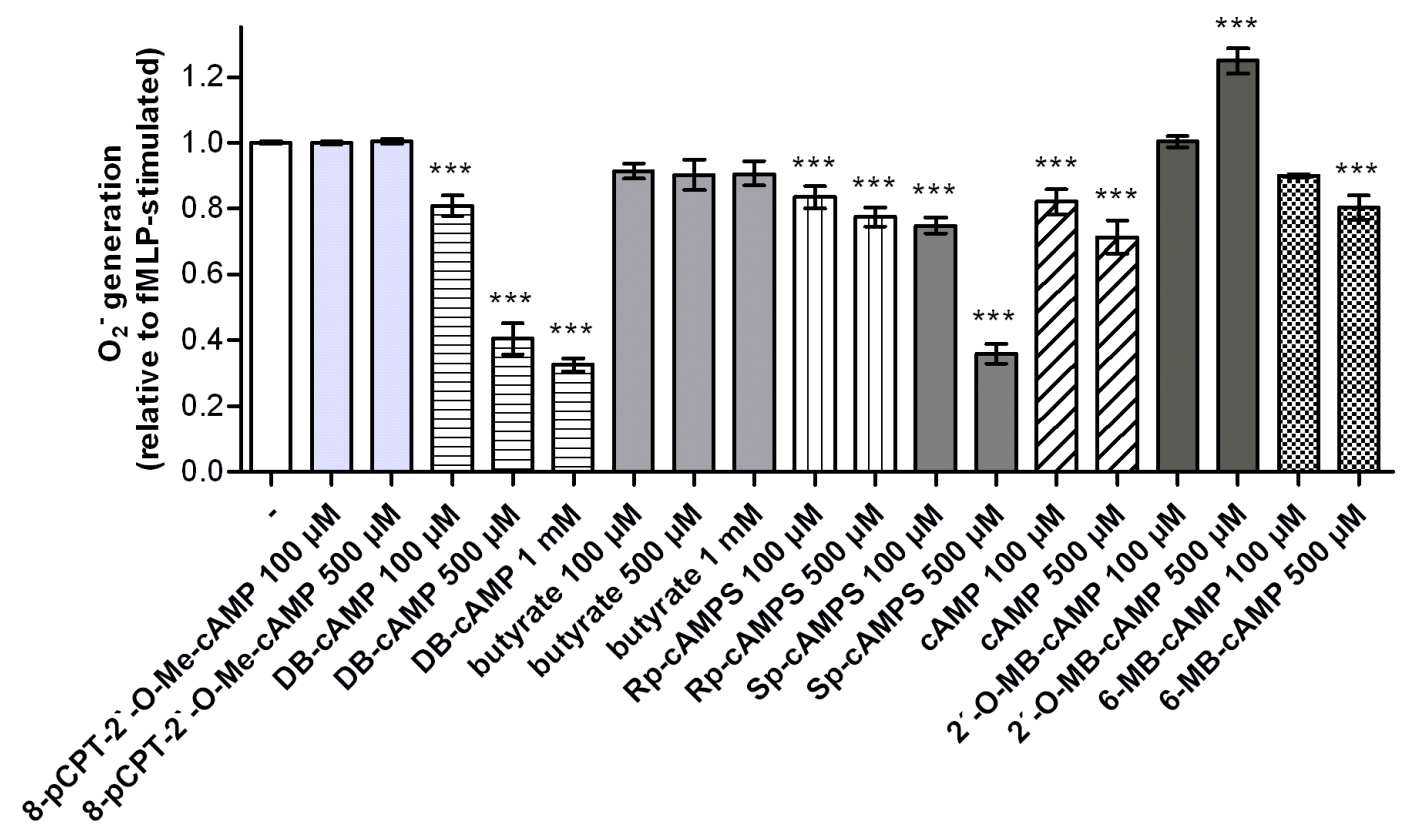

Figure 9. Effects of CAMP, butyrate and CAMP analogs on fMLP-stimulated $\mathrm{O}_{2}{ }^{--}$production. $\mathrm{O}_{2}{ }^{--}$production in human neutrophil granulocytes $\left(1 \times 10^{5}\right.$ cells per well) was monitored by measuring superoxide dismutase-inhibitable reduction of ferricytochrome $\mathrm{c}$ at $550 \mathrm{~nm}$ as described in Materials and Methods. Data shown (mean \pm S.E.M.) are from three to seven independent experiments, performed in triplicate. Data were analyzed for statistical significance relative to the control (-, set to 1.0) using one-way ANOVA, followed by Dunnett's multiple comparison test $(* * * \mathrm{p}<0.001)$.

doi:10.1371/journal.pone.0064556.g009

experimental tools available. Most strikingly, the widely used AC inhibitor SQ 22536 failed to reduce the stimulatory effect of ISO on cAMP levels but further augmented the inhibitory effect of ISO on $\mathrm{O}_{2}{ }^{--}$production (Fig. 8). Non-specific and pleiotropic effects of SQ 22536 have been subject of a recent review [61]. Quite striking too was the lack of inhibitory effect of FSK on $\mathrm{O}_{2}^{\cdot-}$ production and lack of stimulatory effect of FSK on cAMP production (Fig. 8). These data could be explained by a model according to which the FSK-insensitive AC isoform 9 [61] is the functionally predominant AC in neutrophils. This hypothesis needs to be tested in future studies. Again, this is not a trivial task since the quality of $\mathrm{AC}$ antibodies is generally poor [61], and we are not aware of the availability of specific AC9 antibodies.

Stimulation of cAMP accumulation and reduction of $\mathrm{O}_{2}{ }^{--}$ production mediated by ISO, was inhibited according to monophasic competition isotherms by ICI, a highly potent and selective $\beta_{2} \mathrm{AR}$ antagonist with very low potency on the $\beta_{1}$ adrenergic receptor [77]. In case of an exclusive involvement of the $\beta_{1}$-adrenergic receptor we would have expected low potency of ICI, and in case of an involvement of both $\beta$-adrenergic receptors, we would have expected biphasic isotherms. This was clearly not the case (Fig. 5), and moreover, the potency of ICI at the native $\beta_{2} \mathrm{AR}$ was even higher than at the recombinant $\beta_{2} \mathrm{AR}$ (Fig. 5 and Table 2). Thus, the data obtained with ICI provide strong evidence for the notion that only the $\beta_{2} \mathrm{AR}$ but not the $\beta_{1^{-}}$ adrenergic receptor is functionally expressed in human neutrophils. Moreover, we excluded the possibility that ISO as representative $\beta_{2} \mathrm{AR}$ agonist cross-reacts with the histamine $\mathrm{H}_{2}$ receptor, which is also expressed on human neutrophils [40]. Specifically, the effect of ISO on fMLP-induced $\mathrm{O}_{2}{ }^{--}$production was not reduced by the histamine $\mathrm{H}_{2}$ receptor antagonists famotidine, tiotidine and zolantidine (data not shown).

Stallaert and coworkers [78] demonstrated on HEK293S cells that $\beta_{2} \mathrm{AR}$-dependent impedance response to ISO is the result of activation of multiple signaling pathways, including $G_{\mathrm{s}}$ and $\mathrm{G}_{\mathrm{i}}$ coupling, G $\beta \gamma$-dependent signaling, cAMP production, extracellular signal-regulated kinase (ERK) $1 / 2$ activation as well as $\mathrm{Ca}^{2+}$ mobilization. Therefore, when stimulation of the $\beta_{2} \mathrm{AR}$ does not activate the PKA-dependent pathway in human neutrophils or this pathway does not interfere with the NADPH oxidase signaling, modulation of the e.g. ERK1/2-pathway could be the explanation for the inhibition of the NADPH oxidase. Interestingly, in other studies on human neutrophils, a correlation between activation of cAMP/PKA signaling pathway and inhibition of ERK phosphorylation was observed, resulting in reduced fMLP-induced $\mathrm{O}_{2}{ }^{--}$ production $[79,80]$. Intriguingly, the $\beta_{2} \mathrm{AR}$ was reported to activate ERK signaling pathway via interaction with $G_{i}$, Src and/or arrestin proteins in addition to $G_{s}$ proteins in other systems [81]. As it is evident that $\beta_{2} \mathrm{AR}$-signalling strongly depends on the cell system used [16], there is a need to address the correlation between $\beta_{2} \mathrm{AR}$ activation, ERK activation and fMLP-stimulated $\mathrm{O}_{2}{ }^{--}$production in future studies as well. This could provide an explanation for the observed biased effects of some examined $\beta_{2} \mathrm{AR}$ ligands on neutrophils.

In preliminary studies we examined a number of pharmacological inhibitors to explore alternative signaling pathways of the $\beta_{2} \mathrm{AR}$; e.g. we tested the p38 inhibitor SB203580, the JNK inhibitors SP600125 and SP600123, the ERK inhibitor PD980598, the PI3 kinase inhibitor LY294002 and the protein kinase $\mathrm{G}$ inhibitor Goe 6978. Unfortunately, these compounds per se inhibited fMLP-stimulated $\mathrm{O}_{2}{ }^{--}$production (data not shown) so that separate effects of these compounds on ISO actions could not be properly dissected. An alternative approach will be the examination of the effects of $\beta_{2} \mathrm{AR}$ ligands on protein phosphorylation in neutrophils, using screening approaches encompassing numerous protein kinases as starting point. Lastly, it will also be very important to explore the possibility that the new signaling 
molecules cyclic CMP (cCMP) and cyclic UMP (cUMP) [82] are involved in $\beta_{2} \mathrm{AR}$-mediated signal transduction.

Data from the literature suggest a feasible use of $\beta_{2} \mathrm{AR}$ agonists as anti-inflammatory agents $[10,83]$. In order to extend the data on functional selectivity in native test systems, we compared the effect of $\beta_{2} \mathrm{AR}$ ligands on cAMP accumulation and $\mathrm{O}_{2}{ }^{-}$ production in human neutrophils. However, there are many native test systems described, which would afford an expansion of our knowledge about functional selectivity of $\beta_{2} \mathrm{AR}$ ligands. One example could be the parallel measurement of cAMP concentration and contractility of cardiomyocytes or endothelial cells as functional parameter [16,69]. Moreover, a comparison of cAMP accumulation and ERK phosphorylation in e.g. mouse embryonic fibroblasts [84] could be used for screening of $\beta_{2} A R$ ligands. All in all, there is a need to assess biased signaling through the $\beta_{2} \mathrm{AR}$ in a wide spectrum of native test systems in order to improve the desired therapeutic effect of developed compounds on the one and to minimize side effects on the other. Furthermore, $\beta_{2} \mathrm{AR}$ agonists that have been used for many years in the therapy of humans, e.g. as bronchodilators in patients with asthma or chronic obstructive pulmonary disease, should be reassessed using various native test systems, as there is a potential to improve already existing therapies, particularly by minimizing unwanted effects.

As a general approach to study functional selectivity in native cells, it is necessary to construct a systematic data matrix in which multiple ligands are examined at multiple concentrations (enabling determination of precise potencies and efficacies) and for multiple parameters. Previous studies with native human cells may have largely overlooked functional selectivity at GPCRs because there was no appreciation of the necessity to generate such a systematic data collection in order to understand cell biology. It is evident

\section{References}

1. Selvatici R, Falzarano S, Mollica A, Spisani S (2006) Signal transduction pathways triggered by selective formylpeptide analogues in human neutrophils. Eur J Pharmacol 534: 1-11

2. Seifert R, Schultz G (1991) The superoxide-forming NADPH oxidase of phagocytes. An enzyme system regulated by multiple mechanisms. Rev Physiol Biochem Pharmacol 117: 1-338.

3. Morel F, Doussiere J, Vignais PV (1991) The superoxide-generating oxidase of phagocytic cells. Physiological, molecular and pathological aspects. Eur J Biochem 201: 523-546.

4. El-Benna J, Dang PM, Perianin A (2010) Peptide-based inhibitors of the phagocyte NADPH oxidase. Biochem Pharmacol 80: 778-785.

5. Arruda MA, Barja-Fidalgo C (2009) NADPH oxidase activity: In the crossroad of neutrophil life and death. Front Biosci 14: 4546-4556.

6. Burde R, Seifert R, Buschauer A, Schultz G (1989) Histamine inhibits activation of human neutrophils and HL-60 leukemic cells via $\mathrm{H}_{2}$ receptors. NaunynSchmiedeberg's Arch Pharmacol 340: 671-678.

7. Gierschik P, Sidiropoulos D, Jakobs KH (1989) Two distinct $G_{i}$ proteins mediate formyl peptide receptor signal transduction in human leukemia (HL-60) cells. J Biol Chem 264: 21470-21473.

8. Wenzel-Seifert K, Arthur JM, Liu HY, Seifert R (1999) Quantitative analysis of formyl peptide receptor coupling to $\mathrm{G} \alpha_{\mathrm{i} 1}, \mathrm{G} \alpha_{\mathrm{i} 2}$, and $\mathrm{G} \alpha_{\mathrm{i} 3}$. J Biol Chem 274: 33259-33266.

9. Wenzel-Seifert K, Ervens J, Seifert R (1991) Differential inhibition and potentiation by cell-permeant analogues of cyclic AMP and cyclic GMP and NO-containing compounds of exocytosis in human neutrophils. Naunyn Schmiedebergs Arch Pharmacol 344: 396-402.

10. Mirza ZN, Kato M, Kimura H, Tachibana A, Fujiu T, et al. (2002) Fenoterol inhibits superoxide anion generation by human polymorphonuclear leukocytes via $\beta$-adrenoceptor-dependent and -independent mechanisms. Ann Allergy Asthma Immunol 88: 494-500.

11. Mitsuyama T, Takeshige K, Furuno T, Tanaka T, Hidaka K, et al. (1995) An inhibitor of cyclic AMP-dependent protein kinase enhances the superoxide production of human neutrophils stimulated by $\mathrm{N}$-formyl-methionyl-leucylphenylalanine. Mol Cell Biochem 145: 19-24.

12. Mueller H, Motulsky HJ, Sklar LA (1988) The potency and kinetics of the $\beta$ adrenergic receptors on human neutrophils. Mol Pharmacol 34: 347-353.

13. Wong K, Freund K (1981) Inhibition of the N-formylmethionyl-leucylphenylalanine induced respiratory burst in human neutrophils by adrenergic agonists and prostaglandins of the E series. Can J Physiol Pharmacol 59: 915920. that availability of human cells is an issue for comprehensive pharmacological studies. The human neutrophil, despite its inherent problems, i.e. short survival time after isolation, variable responsiveness and poor accessibility to genetic manipulation, is a suitable model system to test functional selectivity for several reasons. Specifically, neutrophils can be obtained in large quantities, express multiple receptors, display numerous cell functions that can be assessed quantitatively and are pathophysiologically relevant for inflammation.

\section{Supporting Information}

Figure S1 Structures of the $\beta_{2} A R$ agonists and antagonists examined in this study.

(PPTX)

\section{Figure S2 Structures of cAMP and cAMP analogs examined in this study. \\ (PPTX)}

\section{Acknowledgments}

We would like to thank J. von der Ohe (Institute of Pharmacology, Medical School of Hannover, Hannover) for her expert technical assistance. We also appreciate a lot the constructive critique of the reviewers.

\section{Author Contributions}

Conceived and designed the experiments: IBH RS. Performed the experiments: IBH MTR SK HB. Analyzed the data: IBH SK HB MTR FS AB RS. Contributed reagents/materials/analysis tools: HB FS. Wrote the paper: IBH MTR AB RS

14. Lad PM, Goldberg BJ, Smiley PA, Olson CV (1985) Receptor-specific threshold effects of cyclic AMP are involved in the regulation of enzyme release and superoxide production from human neutrophils. Biochim Biophys Acta 846: 286-295.

15. Wenzel-Seifert K, Seifert R (2000) Molecular analysis of $\beta_{2}$-adrenoceptor coupling to $G_{s}, G_{i}$, and $G_{q}$ proteins. Mol Pharmacol 58: $954-966$.

16. Evans BA, Sato M, Sarwar M, Hutchinson DS, Summers RJ (2010) Liganddirected signalling at $\beta$-adrenoceptors. Br J Pharmacol 159: 1022-1038.

17. Drake MT, Violin JD, Whalen EJ, Wisler JW, Shenoy SK, et al. (2008) $\beta$ Arrestin-biased agonism at the $\beta_{2}$-adrenergic receptor. J Biol Chem 283: 5669 5676 .

18. Audet M, Bouvier M (2008) Insights into signaling from the $\beta_{2}$-adrenergic receptor structure. Nat Chem Biol 4: 397-403.

19. Rosenbaum DM, Rasmussen SG, Kobilka BK (2009) The structure and function of G-protein-coupled receptors. Nature 459: 356-363.

20. Seifert R, Wenzel-Seifert K (2002) Constitutive activity of G protein-coupled receptors: cause of disease and common property of wild-type receptors. Naunyn Schmiedebergs Arch Pharmacol 366: 381-416.

21. Neubig RR, Spedding M, Kenakin T, Christopoulos A (2003) International Union of Pharmacology Committee on Receptor Nomenclature and Drug Classification. XXXVIII. Update on terms and symbols in quantitative pharmacology. Pharmacol Rev 55: 597-606.

22. Kenakin $\mathrm{T}$ (2004) Principles: receptor theory in pharmacology. Trends Pharmacol Sci 25: 186-192.

23. Gether U, Lin S, Kobilka BK (1995) Fluorescent labeling of purified $\beta_{2}$ adrenergic receptor. Evidence for ligand-specific conformational changes. J Biol Chem 270: 28268-28275.

24. Seifert R, Gether U, Wenzel-Seifert K, Kobilka BK (1999) Effects of guanine, inosine, and xanthine nucleotides on $\beta_{2}$-adrenergic receptor $/ G_{\mathrm{s}}$ interactions: evidence for multiple receptor conformations. Mol Pharmacol 56: 348-358.

25. Sternini C, Spann M, Anton B, Keith DE, Jr., Bunnett NW, et al. (1996) Agonist-selective endocytosis of $\mu$ opioid receptor by neurons in vivo. Proc Natl Acad Sci USA 93: 9241-9246.

26. Galandrin S, Bouvier M (2006) Distinct signaling profiles of $\beta_{1^{-}}$and $\beta_{2^{-}}$ adrenergic receptor ligands toward adenylyl cyclase and mitogen-activated protein kinase reveals the pluridimensionality of efficacy. Mol Pharmacol 70: $1575-1584$.

27. Rajagopal S, Rajagopal K, Lefkowitz RJ (2010) Teaching old receptors new tricks: biasing seven-transmembrane receptors. Nat Rev Drug Discov 9: 373386. 
28. Kobilka BK, Deupi X (2007) Conformational complexity of G protein-coupled receptors. Trends Pharmacol Sci 28: 397-406.

29. Kenakin T (1995) Agonist-receptor efficacy. II. Agonist trafficking of receptor signals. Trends Pharmacol Sci 16: 232-238.

30. Tucek S (1997) Is the R and R dichotomy real? Trends Pharmacol Sci 18: 414 416

31. Liu JJ, Horst R, Katritch V, Stevens RC, Wüthrich K (2012) Biased signaling pathways in $\beta_{2}$-adrenergic receptor characterized by $19 \mathrm{~F}-\mathrm{NMR}$. Science 335 : $1106-1110$.

32. Galandrin S, Oligny-Longpré G, Bouvier M (2007) The evasive nature of drug efficacy: implications for drug discovery. Trends Pharmacol Sci 28: 423-430.

33. Kenakin T, Miller LJ (2010) Seven transmembrane receptors as shapeshifting proteins: the impact of allosteric modulation and functional selectivity on new drug discovery. Pharmacol Rev 62: 265-304.

34. Rosethorne EM, Charlton SJ (2011) Agonist-biased signaling at the histamine $\mathrm{H}_{4}$ receptor: JNJ7777120 recruits $\beta$-arrestin without activating $\mathrm{G}$ proteins. Mol Pharmacol 79: 749-757.

35. Azzi M, Charest PG, Angers S, Rousseau G, Kohout T, et al. (2003) $\beta$-arrestinmediated activation of MAPK by inverse agonists reveals distinct active conformations for G protein-coupled receptors. Proc Natl Acad Sci USA 100: $11406-11411$

36. Thomas RL, Mistry R, Langmead CJ, Wood MD, Challiss RA (2008) G protein coupling and signaling pathway activation by $\mathrm{M}_{1}$ muscarinic acetylcholine receptor orthosteric and allosteric agonists. J Pharmacol Exp Ther 327: 365374.

37. Swaminath G, Deupi X, Lee TW, Zhu W, Thian FS, et al. (2005) Probing the $\beta_{2}$-adrenoceptor binding site with catechol reveals differences in binding and activation by agonists and partial agonists. J Biol Chem 280: 22165-22171.

38. Kahsai AW, Xiao K, Rajagopal S, Ahn S, Shukla AK, et al. (2011) Multiple ligand-specific conformations of the $\beta_{2}$-adrenergic receptor. Nat Chem Biol 7: 692-700.

39. Granier S, Kim S, Shafer AM, Ratnala VR, Fung JJ, et al. (2007) Structure and conformational changes in the C-terminal domain of the $\beta_{2}$-adrenoceptor: insights from fluorescence resonance energy transfer studies. J Biol Chem 282: 13895-13905.

40. Reher TM, Brunskole I, Neumann D, Seifert R (2012) Evidence for ligandspecific conformations of the histamine $\mathrm{H}_{2}$-receptor in human eosinophils and neutrophils. Biochem Pharmacol 84: 1175-1185.

41. Beste KY, Burhenne H, Kaever V, Stasch JP, Seifert R (2012) Nucleotidyl cyclase activity of soluble guanylyl cyclase $\alpha_{1} \beta_{1}$. Biochemistry 51: 194-204.

42. Kinast L, von der Ohe J, Burhenne H, Seifert R (2012) Impairment of adenylyl cyclase 2 function and expression in hypoxanthine phosphoribosyltransferasedeficient rat B103 neuroblastoma cells as model for Lesch-Nyhan disease: BODIPY-forskolin as pharmacological tool. Naunyn Schmiedebergs Arch Pharmacol 385: 671-683.

43. Weitl N, Seifert R (2008) Distinct interactions of human $\beta_{1^{-}}$and $\beta_{2^{-}}$ adrenoceptors with isoproterenol, epinephrine, norepinephrine, and dopamine. J Pharmacol Exp Ther 327: 760-769.

44. Cheng Y, Prusoff WH (1973) Relationship between the inhibition constant (K1) and the concentration of inhibitor which causes 50 per cent inhibition (I50) of an enzymatic reaction. Biochem Pharmacol 22: 3099-3108.

45. Seifert R, Wenzel-Seifert K, Lee TW, Gether U, Sanders-Bush E, et al. (1998) Different effects of $G_{s \alpha}$ splice variants on $\beta_{2}$-adrenoreceptor-mediated signaling. The $\beta_{2}$-adrenoreceptor coupled to the long splice variant of $\mathrm{G}_{\mathrm{s} \alpha}$ has properties of a constitutively active receptor. J Biol Chem 273: 5109-5116.

46. Seifert R, Hilgenstock G, Fassbender M, Distler A (1991) Regulation of the superoxide-forming NADPH oxidase of human neutrophils is not altered in essential hypertension. J Hypertens 9: 147-153.

47. Hill SJ (2006) G protein-coupled receptors: past, present and future. Br J Pharmacol 147 Suppl 1: S27-37.

48. Baker JG, Hall IP, Hill SJ (2003) Influence of agonist efficacy and receptor phosphorylation on antagonist affinity measurements: differences between second messenger and reporter gene responses. Mol Pharmacol 64: 679-688.

49. Appl H, Holzammer T, Dove S, Haen E, Strasser A, et al. (2011) Interactions of recombinant human histamine $\mathrm{H}_{1}, \mathrm{H}_{2}, \mathrm{H}_{3}$ and $\mathrm{H}_{4}$ receptors with 34 antidepressants and antipsychotics. Naunyn Schmiedebergs Arch Pharmacol 385: $145-170$

50. Gibson-Berry KL, Whitin JC, Cohen HJ (1993) Modulation of the respiratory burst in human neutrophils by isoproterenol and dibutyryl cyclic AMP. J Neuroimmunol 43: 59-68.

51. Barnett CC, Jr., Moore EE, Partrick DA, Silliman CC (1997) Beta-adrenergic stimulation down-regulates neutrophil priming for superoxide generation, but not elastase release. J Surg Res 70: 166-170.

52. Hidaka H, Inagaki M, Kawamoto S, Sasaki Y (1984) Isoquinolinesulfonamides, novel and potent inhibitors of cyclic nucleotide dependent protein kinase and protein kinase C. Biochemistry 23: 5036-5041.

53. Rothermel JD, Jastorff B, Botelho LH (1984) Inhibition of glucagon-induced glycogenolysis in isolated rat hepatocytes by the $\mathrm{Rp}$ diastereomer of adenosine cyclic 3',5'-phosphorothioate. J Biol Chem 259: 8151-8155.

54. Lazarovici P, Rasouly D, Friedman L, Tabekman R, Ovadia H, et al. (1996) $\mathrm{K} 252 \mathrm{a}$ and staurosporine microbial alkaloid toxins as prototype of neurotropic drugs. Adv Exp Med Biol 391: 367-377.

55. Uemura T, Ohta Y, Nakao Y, Manaka T, Nakamura H, et al. (2010) Epinephrine accelerates osteoblastic differentiation by enhancing bone morpho- genetic protein signaling through a cAMP/protein kinase A signaling pathway. Bone 47: 756-765

56. Kellenberger S, Muller K, Richener H, Bilbe G (1998) Formoterol and isoproterenol induce c-fos gene expression in osteoblast-like cells by activating $\beta_{2}$-adrenergic receptors. Bone 22: 471-478.

57. Hoogland TM, Saggau $\mathrm{P}(2004)$ Facilitation of L-type $\mathrm{Ca}^{2+}$ channels in dendritic spines by activation of $\beta_{2}$ adrenergic receptors. J Neurosci 24: 8416-8427.

58. Madden KS, Szpunar MJ, Brown EB (2011) $\beta$-Adrenergic receptors $(\beta$-AR) regulate VEGF and IL-6 production by divergent pathways in high $\beta$-ARexpressing breast cancer cell lines. Breast Cancer Res Treat 130: 747-758.

59. Dostmann WRG, Taylor SS, Genieser HG, Jastorff B, Døskeland SO, et al. (1990) Probing cyclic nucleotide binding sites of cAMP-dependent protein kinase I and II with analogs of adenosine $3^{\prime}, 5^{\prime}$-cyclic phosphorothioates. J Biol Chem 265: 10484-10491.

60. Hourani SM, Boon K, Fooks HM, Prentice DJ (2001) Role of cyclic nucleotides in vasodilations of the rat thoracic aorta induced by adenosine analogues. Br J Pharmacol 2001;133: 833-40.

61. Seifert R, Lushington GH, Mou TC, Gille A, Sprang SR (2012) Inhibitors of membranous adenylyl cyclases. Trends Pharmacol Sci 33: 64-78.

62. Kaukel E, Mundhenk $\mathrm{K}$, Hilz $\mathrm{H}$ (1972) $\mathrm{N}^{6}$-monobutyryladenosine $3^{\prime} \cdot 5^{\prime}$ monophosphate is the biologically active derivative of dibutyryladenosine $3^{\prime}: 5^{\prime}$ monophosphate in HeLa S3 cells. Eur J Biochem 27: 197-200.

63. Jackson EK, Raghvendra DK (2004) The extracellular cyclic AMP-adenosine pathway in renal physiology. Annu Rev Physiol 66: 571-599.

64. Russel FG, Koenderink JB, Masereeuw R (2008) Multidrug resistance protein 4 (MRP4/ABCC4): a versatile efflux transporter for drugs and signalling molecules. Trends Pharmacol Sci 29: 200-207.

65. Gloerich M, Bos JL (2010) Epac: defining a new mechanism for cAMP action. Annu Rev Pharmacol Toxicol 50: 355-375.

66. Seifert R, Dove S (2009) Functional selectivity of GPCR ligand stereoisomers: new pharmacological opportunities. Mol Pharmacol 75: 13-18.

67. Mukhopadhyay S, Howlett AC (2005) Chemically distinct ligands promote differential $\mathrm{CB}_{1}$ cannabinoid receptor- $\mathrm{G}_{\mathrm{i}}$ protein interactions. Mol Pharmacol 67: 2016-2024.

68. Reher TM, Neumann D, Buschauer A, Seifert R (2012) Incomplete activation of human eosinophils via the histamine $\mathrm{H}_{4}$-receptor: Evidence for ligand-specific receptor conformations. Biochem Pharmacol 84: 192-203.

69. Woo AY, Wang TB, Zeng X, Zhu W, Abernethy DR, et al. (2009) Stereochemistry of an agonist determines coupling preference of $\beta_{2}$-adrenoceptor to different $\mathrm{G}$ proteins in cardiomyocytes. Mol Pharmacol 75: 158-165.

70. Carbonetti NH (2010) Pertussis toxin and adenylate cyclase toxin: key virulence factors of Bordetella pertussis and cell biology tools. Future Microbiol 5: 455469.

71. Orlic T, Loomis WH, Shreve A, Namiki S, Junger WG (2002) Hypertonicity increases cAMP in PMN and blocks oxidative burst by PKA-dependent and independent mechanisms. Am J Physiol Cell Physiol 282: C1261-C1269.

72. Sedgwick JB, Berube ML, Zurier RB (1985) Stimulus-dependent inhibition of superoxide generation by prostaglandins. Clin Immunol Immunopathol 34: 205-215.

73. Cronstein BN, Kramer SB, Rosenstein ED, Korchak HM, Weissmann G, et al. (1988) Occupancy of adenosine receptors raises cyclic AMP alone and in synergy with occupancy of chemoattractant receptors and inhibits membrane depolarization. Biochem J 252: 709-715

74. Costantini TW, Deree J, Peterson CY, Putnam JG, Woon T, et al. (2010) Pentoxifylline modulates p47phox activation and downregulates neutrophil oxidative burst through PKA-dependent and -independent mechanisms. Immunopharmacol Immunotoxicol 32: 82-91.

75. Costa T, Klinz FJ, Vachon L, Herz A (1988) Opioid receptors are coupled tightly to $\mathrm{G}$ proteins but loosely to adenylate cyclase in NG108-15 cell membranes. Mol Pharmacol 34: 744-7454.

76. Werner K, Schwede F, Genieser HG, Geiger J, Butt E (2011) Quantification of cAMP and cGMP analogs in intact cells: pitfalls in enzyme immunoassays for cyclic nucleotides. Naunyn Schmiedebergs Arch Pharmacol 384: 169-176.

77. Brodde OE, Michel MC (1995) Adrenergic and muscarinic receptors in the human heart. Pharmacol Rev 51: 651-690.

78. Stallaert W, Dorn JF, van der Westhuizen E, Audet M, Bouvier M (2012) Impedance responses reveal $\beta_{2}$-adrenergic receptor signaling pluridimensionality and allow classification of ligands with distinct signaling profiles. PLoS One 7: e29420.

79. Liao CH, Lin SZ, Tseng CP, Day YJ, Chang CS, et al. (2008) A benzodiazepines derived compound, 4-(3-chlorophenyl)-1,3-dihydronaphtho 2,3-b]1,4]diazepin-2-one (ND700C), inhibits fMLP-induced superoxide anion release by activating protein phosphatase $2 \mathrm{~A}$ in human neutrophils. Biochem Pharmacol 76: 1728-1739.

80. Liu FC, Day YJ, Liou JT, Yu HP, Liao HR (2012) Splitomicin inhibits fMLPinduced superoxide anion production in human neutrophils by activate cAMP/ PKA signaling inhibition of ERK pathway. Eur J Pharmacol 688: 68-75.

81. Kaya AI, Onaran HO, Ozcan G, Ambrosio C, Costa T, et al. (2012) Cell contact-dependent functional selectivity of $\beta_{2}$-adrenergic receptor ligands in stimulating cAMP accumulation and extracellular signal-regulated kinase phosphorylation. J Biol Chem 287: 6362-6374

82. Beste KY, Seifert R (2013) cCMP, cUMP, cTMP, cIMP and cXMP as possible second messengers: development of a hypothesis based on studies with soluble guanylyl cyclase $\alpha_{1} \beta_{1}$. Biol Chem 394: 261-270. 
83. Uzkeser H, Cadirci E, Halici Z, Odabasoglu F, Polat B, et al. (2012) Antiinflammatory and antinociceptive effects of salbutamol on acute and chronic models of inflammation in rats: involvement of an antioxidant mechanism. Mediators Inflamm 2012: 438912.
84. Sun Y, Huang J, Xiang Y, Bastepe M, Juppner H, et al. (2007) Dosagedependent switch from $\mathrm{G}$ protein-coupled to $\mathrm{G}$ protein-independent signaling by a GPCR. EMBO J 26: 53-64. 